Article

\title{
Public Debt, Corruption and Sustainable Economic Growth
}

\author{
Eunji Kim ${ }^{1}$, Yoonhee $\mathrm{Ha}^{2}$ and Sangheon Kim ${ }^{3, *}$ \\ 1 Gender Budget Research Center, Korea Women's Development Institute, Seoul 03367, Korea; \\ ejkim@kwdimail.re.kr \\ 2 Graduate School of Energy and Environment, Korea University, Seoul 02841, Korea; helloyunie@korea.ac.kr \\ 3 Graduate School of Public Administration and the Korea Institute of Public Affairs, Seoul National \\ University, Seoul 08826, Korea \\ * Correspondence: sanghkim@snu.ac.kr; Tel.: +82-2-880-9318
}

Academic Editors: JinHyo Joseph Yun and Tan Yigitcanlar

Received: 13 December 2016; Accepted: 23 February 2017; Published: 15 March 2017

\begin{abstract}
There are many studies that look into the relationship between public debt and economic growth. It is hard to find, however, research addressing the role of corruption between these two variables. Noticing this vacancy in current literature, we strive to investigate the effect of corruption on the relationship between public debt and economic growth. For this purpose, the pooled ordinary least squares (OLS), fixed effects models and the dynamic panel generalized method of moments (GMM) models (Arellano-Bond, 1991) are estimated with data of 77 countries from 1990 to 2014. The empirical results show that the interaction term between public debt and corruption is statistically significant. This confirms the hypothesis that the effect of public debt on economic growth is a function of corruption. The sign of the marginal effect is negative in corrupt countries, but public debt enhances economic growth within countries that are not corrupt, i.e., highly transparent.
\end{abstract}

Keywords: public debt; economic growth; corruption; institution

\section{Introduction}

We have witnessed big increases in public debt levels across countries after the recent economic crisis. As can be seen in the following Figure 1, the public debt ratio to GDP has increased quite sharply following the global economic crisis of 2008, and this phenomenon is prevalent across advanced countries (A referee suggests that it should be acknowledged that the surge in public debt, particularly after the 2007/08 crisis, was to some great extent a consequence of the nationalization of private debt). The debt ratio has surpassed 1.0 in several countries including Japan, Greece and Italy. The persistent growth in public debt has raised serious concerns regarding fiscal sustainability and its effect on the economy. For instance, Reinhart and Rogoff [1] suggested a threshold for public debt under which each country is recommended to remain below in order to prevent any risk of default.

Concerns over the sharp rise in public debt levels seem to reflect the possibility of harmful effects of public debt on economic growth (There is another line of research focusing on the harmful effect of private debt on the economy (Keen [2], Hien and van Treeck [3])). Sustainable growth is and has been one of the main goals of every government and thus researchers are interested in looking into public debt levels and their effects on various economies. It is likely that researchers consider public debt to work as a necessary condition for sustainable growth.

Many studies to date focus on the relationship between public debt and economic growth. Most argue a negative effect of public debt on growth. There is, however, research showing different results. Notwithstanding the abundant literature, it is hard to find research that addresses the role corruption plays between these two variables. Noticing this vacancy in the literature, we try to 
investigate the effect of corruption on the relationship between public debt and economic growth. The main hypothesis we aim to test is whether or not the marginal effect of public debt on growth is a function of corruption.

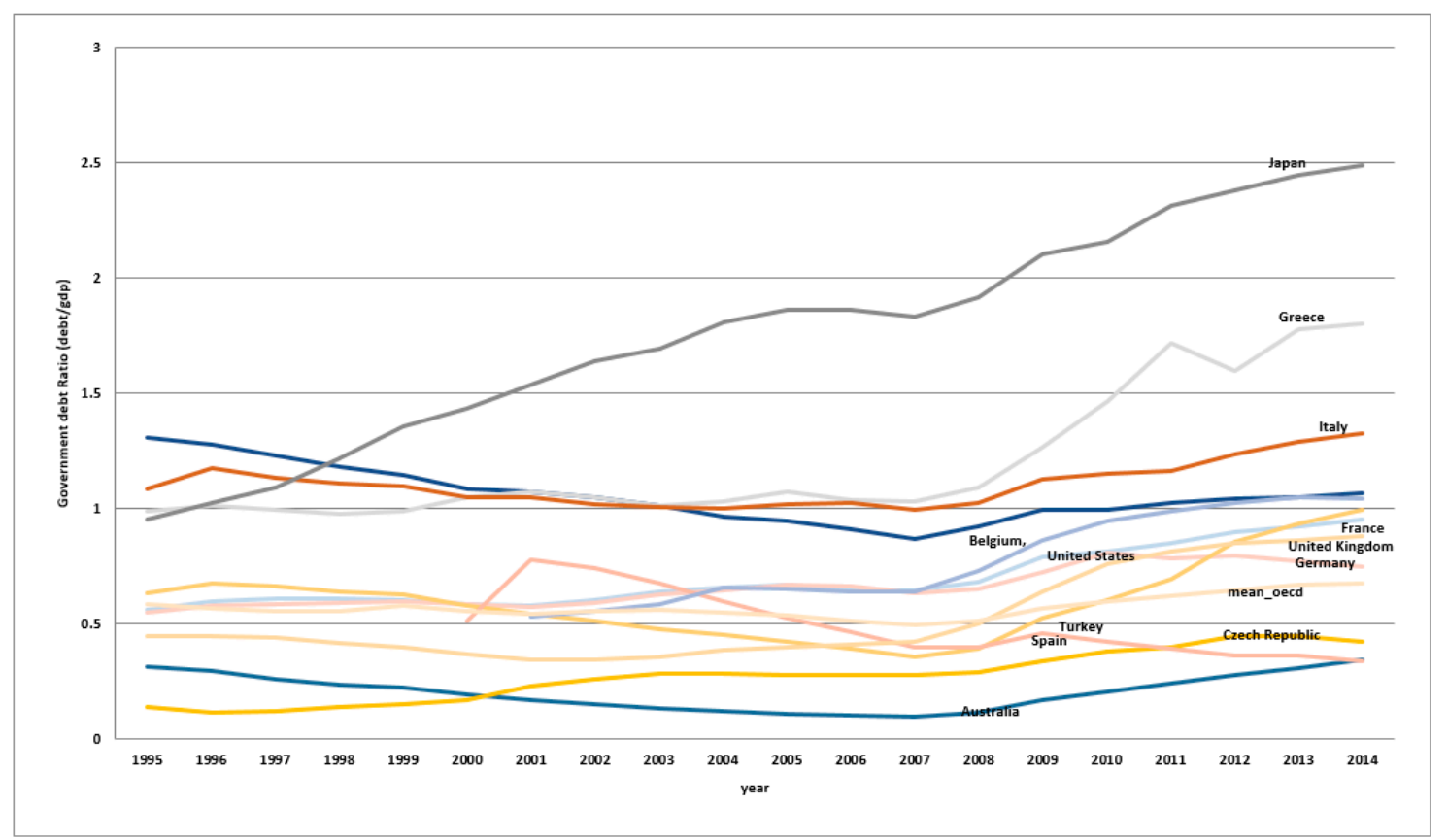

Figure 1. Public debt across countries (notes: debt is defined to be general government's gross debt. Data are from the International Monetary Fund (IMF) world economic outlook, IMF, 2016).

For this purpose, we utilize various regression models. The pooled ordinary least squares (OLS), fixed effects models and the dynamic panel generalized method of moments (GMM) models (Arellano-Bond [4]) are estimated with the data of 77 countries from 1990 to 2014. The empirical results show that the interaction term between public debt and corruption is statistically significant. This confirms the hypothesis that the effect of public debt on economic growth is a function of corruption. Even if the threshold differentiating the sign of the marginal effect is dependent upon models selected, we can conclude that in the case of a highly transparent-not corrupt-country, public debt enhances economic growth and vice versa. To check the robustness of the estimation results, we also estimate five-year and ten-year average models. We also vary the sample size. That is, we estimate the same models for different groups of countries: 38 countries, 46 countries as well as 77 countries. We conclude that the estimation results are robust to the changes in models (five-year average model) and the same size.

As far as we know, this is the first study that reveals the moderating effect of corruption on the relationship between public debt and economic growth. More specifically, this paper has its originality in the effort to test empirically whether the marginal effect of public debt on growth is a function of corruption. Jalles [5] also tried to examine the marginal effect, but he came up with an ambiguous and contrary conclusion to the theoretical prediction. We expect the empirical results to contribute to a better understanding of the association of public debt with economic growth. Furthermore, this study aims to generate deeper and richer analyses in the field of public debt from which useful policy implications may be derived.

The remainder of the paper is organized as follows. The next section introduces a literature review on public debt and economic growth. In Section 3, we explain the importance of institutions in determining the association between public debt and economic growth. Section 4 contains empirical 
models and analyses, and presents major findings. We conclude and suggest policy implications in the final section.

\section{Background}

\subsection{Public Debt and Economic Growth}

The topic of public debt has long been an important issue in research. The main focus lies in the relationship between public debt and economic growth. The conventional view (named by 'saltwater' economists) asserts that in the short term, aggregate output can be boosted, but in the long run, investment is reduced and therefore economic growth is harmed (for a thorough literature review of this line of reasoning, refer to Elmendorf and Mankiw [6]). The seminal work by Barro [7], however, shows an opposing view. Based on the permanent income hypothesis and rational behavior of economic agents, he suggests that people prepare for any future burden caused by public debt, and as a result, save the corresponding amount of money and therefore, investment and economic growth will not be affected. This line of research is referred to as 'Ricardian equivalence' (named after David Ricardo).

These contrasting views on the association between public debt and economic growth have generated a fair amount of further research, mainly testing the hypothesis of 'Ricardian equivalence.' Earlier studies aim to theoretically contradict or to find empirical evidence against the hypothesis: [8-11]. Some studies, however, support Barro's idea of 'Ricardian equivalence': [12-14]. In contrast, Haug [15] produces mixed results, dependent upon the data set. Notwithstanding the abundance of studies, the debate has not yet been resolved. Recent studies also present mixed results: some support the view [16,17], whereas others provide evidence against it [18-20]. Evans [21] derives conditions under which Ricardian equivalence holds even in the case of non-rational expectation behavior. In addition, many recent studies test whether the hypothesis holds in any specific country [22-25]. Choi and Holmes [26] present a different view by stating that a long-horizon data set shows a mixture of two regimes, Ricardian equivalence and non-Ricardian equivalence regimes.

Apart from the studies that test the idea of Ricardian equivalence, a line of research focuses on investigating the association between public debt and economic growth directly. Several channels are suggested through which public debt can adversely affect economic growth. Some studies emphasize that high public debt leads to higher long-term interest rates and sovereign risk spillovers to borrowing costs of corporations [27-29]. Other studies look at the channel of higher distortionary taxation caused by high public debt [30,31]. Aizenman et al. [32], however, adopts the channel of lower public infrastructure expenditure. On the contrary, Sargent and Wallace [33], Barro [34], and Cocharane [35] emphasize the effect of public debt on higher inflation. High public debt levels may constrain discretionary countercyclical fiscal policies and therefore generate higher volatility of the economy, lowering economic growth [36,37]. Burnside et al. [38] and Hemming et al. [39] notice the triggering effect of a debt crisis on a banking and currency crisis, which is a more extreme case of economic volatility.

More recently, the interest in public debt has moved toward a more empirical investigation of the effects of public debt on economic growth. Most of the earlier empirical studies utilize data from low-income countries. Schclarek [40], however, looks at industrial and developing economies from 1970 to 2002. Reinhart and Rogoff [1] also analyze 20 developed countries for the period of 1946 to 2009. Caner et al. [41] use data of 79 developed and developing countries from 1980 to 2008. Ursua and Wilson [42] also utilize advanced and emerging market data from 1950 to 2010. Checherita and Rother [43] and Baum et al. [44] look at 12 European countries from 1970 to 2008 and 1990 to 2010, respectively. Cechetti et al. [45] and Panizza and Presbitero [46] both investigate OECD countries from 1980 to 2005. Balassone et al. [47] has looked at one country, Italy for a long period time, from 1861 to 2010. Casni et al. [48] deals with Central, Eastern and Southeastern European countries. The most recent study to our knowledge is by Woo and Kumar [49], which looks at advanced and emerging 
countries. Most of these empirical studies conclude that higher debt has harmful effects on economic growth. Even if the magnitude of the harmful effect of debt on growth varies, it is estimated that a $10 \%$ increase in debt-to-GDP ratio reduces $0.1-0.2$ percentage points in annual growth on average.

Even if many of the previous studies determine a negative association of public debt with economic growth, there is a contrasting view. This line of research emphasizes the importance of the composition and purpose of debt or non-linearity of the relationship between them. Some argue that public borrowing can enhance the economy when it is intended for public investment. Modigliani et al. [50], Creel and Fitoussi [51], Le Cacheux [52] and Blanchard and Giavazzi [53] support the idea of 'the Golden Rule of Public Finance (GRPF).' The main idea behind the Golden Rule is that public borrowing is harmful only when it is used for current expenditure but not when it accumulates public capital, i.e., the purpose and composition of public borrowing matters. There is, however, little consensus about the validity of the GRPF. Balassone and Franco [54], Buiter [55], Buti et al. [56], and Minea and Villieu [57] question the positive effect of GRPF. Balassone and Franco [54] emphasize that the GRPF will result in a bias towards over-accumulation of physical assets at the expense of health and education expenditures.

Another line of research focusing on a different aspect of public debt is related with the non-linearity of the effect of public debt on economic growth. Reinhart and Rogoff [1] suggest that high levels of debt are negatively correlated with economic growth, though there is no link between debt and growth when public debt is below $90 \%$ of GDP. Using data from 100 developing countries, Pattillo et al. [58] show a non-linear relationship between the net present value of external debt and economic growth. They suggest that the marginal effect of debt is negative when the net present value of debt surpasses $20 \%$ of GDP. Cordella et al. [59], however, find a negative relationship between external public debt and growth only in developing countries with intermediate levels of debt. The relationship disappears in developing countries with very low or very high levels of debt. They also find that, in countries with bad policies, debt may not matter at all.

To summarize, the literature with regard to the relationship between public debt and economic growth is very rich and diverse. However, there is little consensus about the effect of public debt on economic performance, whereas the majority of the previous studies supports a negative effect. This implies that there is room for further studies to investigate the effect with better data and/or from a different perspective.

\subsection{Public Debt, Institutions and Economic Growth (This Section Has Benefited Largely from the Comments of Two Anonymous Referees)}

Besides the abundant research on the relationship between public debt and economic growth, an important factor has been ignored to an extreme extent, that is, the role of institutions (To the best of our knowledge, the exceptions are Jalles [5], Gonzales-Fernadez and Gonzalez-Velasco [60], and Cooray [61]). It is well known that we live in a society characterized by various types of institutions. According to North [62], institutions are "the rules of the game in a society or, ... the humanly devised constraints that shape human interaction". Good institutions might induce higher investment and therefore lead to sustainable economic growth. It is also noticeable that the type of interest group activities regarding unlawful and/or distortionary (not productive) appropriation of resources can be checked by good institutional arrangements. Good institutions might also reduce uncertainty for economic decision-makers and offer incentives towards innovative and productive activities. Recent empirical evidence supports this assertion. Égert [63] shows that regulation and institutions affect productivity in OECD countries. Dort et al. [64] presents evidence that investment spurs economic growth only in those countries where institutions are not weak. Berggren et al. [65] finds that institutional quality and instability are positively associated with economic growth in 35 European countries. The open innovation theory focuses on structures and institutions that beat growth limits of capitalism. Yun [66] presents the Open Innovation Economic System (OIES) in which new technologies, ideas, and money flow through major agents of the system such as customers, small- and medium-sized 
enterprises (SMEs), start-ups, big businesses, and social entrepreneurs. The virtual circulation and fair distribution of resources create new markets and jobs and bring a breakthrough to the economy's growth halt. Along the same lines, Yun et al. [67] proposes building up a global governance to promote open innovation and suggests institutions for it in the form of an open letter to the Secretary General of the UN.

Whereas the significance of the role institutions play within each country is a consensus view, measuring the quality of an institution is a different story. Since there are various kinds of measures that assess the quality of an institution, it is inevitable that a measurement problem arises. In this paper, we focus on the role of corruption as a measurement of a good institution. Rather than adopting a direct measure, we choose corruption level as a good proxy of institutional quality. We believe that corruption as a measure of institution weakens the measurement problem since it is an outcome resulting from institutional arrangements.

The importance of corruption has been widely recognized in many previous studies and the number of studies on corruption is vast. Many of them explore the effect of corruption on economic performance and the majority of these studies finds a negative association [68-70]. Some studies show that corruption reduces investment [68,71,72] and foreign direct investment [73,74]. Lambsdorff [75] presents a result showing that corruption lowers productivity. Corruption is also shown to be harmful to the economy through higher inflation [76,77] and a bigger shadow economy [78-80].

Another variable in the association with corruption that has attracted attention in the public finance field is government expenditure. Mauro [81] analyzes the components of public expenditure and shows that corruption lowers the levels of expenditure on education and health. He asserts that some items of public expenditure are more attractive than others in acquiring illegal rents and bribes, leading to corruption in the public sector. Justesen et al. [82] shows that corruption lowers government expenditure on the poor and adversely affects them. Dzhmashev [83] shows that the interaction between corruption and governance shapes the efficiency of public spending, which in turn, determines the growth effects of corruption. In any case, a corrupt bureaucracy distorts the purpose and functionality of the public sector, and alters the burden it creates and the structure of spending. D'Agostino et al. [84,85] show that the interactions between corruption and investment and corruption and military spending have strong negative impacts on economic growth.

There is, however, a different view emphasizing a positive effect of corruption on economic growth. According to Leff [86], corruption tends to reduce bureaucratic red tape, boosting economic growth. Others [74,87-91] also support this view. Lau et al. [92] suggest the view that corruption may lead to a lower uncertainty about government policy. In the meantime, there are other studies showing that the growth effect of corruption is dependent upon the institutional setting [93-99]. Mendez and Sepulveda [100] find that the growth-maximizing level of corruption is significantly greater than zero, with corruption beneficial for economic growth at low levels of incidence and detrimental at high levels of incidence.

Studies more directly related to public debt, however, are those that look into the effect of corruption on debt. Gonzales-Fernadez and Gonzalez-Velasco [60] show that corruption has a direct and significant positive effect on public debt in Autonomous Communities of Spain. Cooray et al. [61] also present that increased corruption leads to an increase in public debt. Pattillo et al. [101] interacts debt ratios with a measure of country policies and find that for highly indebted countries the negative impact of debt on growth is stronger for countries with bad policies. Jalles [5] tries to examine the role of corruption as a moderating variable in the association of public debt with economic performance as Pattillo et al. [58] do with the quality of policies.

As seen in the discussion above, corruption might affect economic performance and public finance variables such as government expenditure and public debt. Among them, we focus on the role of corruption as a moderating factor in the association of public debt with economic growth. There might be several channels through which corruption may affect the relationship between debt and growth. First of all, a low level of corruption prevents distortionary misallocation of resources caused by public 
debt. If the revenue raised by public debt is used for unproductive spending in a corrupt country, more debt implies a bad effect on the economy. Shleifer and Vishny [99] argue that high levels of corruption tend to shift loan resources away from high-value projects such as health and education into potentially unproductive projects such as defense and infrastructure. The result by Park [102] is also in line with this view. He shows that corruption distorts the allocation of bank funds from normal projects to bad projects, which decreases the quality of private investments, leading to a lower economic growth. Second, corrupt governments tend to borrow more than governments characterized by lower levels of corruption because they have a higher discount of the future than the latter (Jalles [5]). Over-borrowing caused by corruption might harm the whole economy. Third, according to Ciocchini et al. [103], the quality of governance may increase the probability of default in a country. This implies that more corruption is detrimental to economic growth because of the increased uncertainty.

In any case, corruption plays a negative role in the association of public debt with economic growth. One may expect that a corrupt country would face a negative effect of public debt on economic growth whereas it might be possible to witness a positive relationship between them in countries that are not corrupt. The basic idea of this paper is that the effect of public debt on economic growth is not homogeneous across countries. Public debt itself may not be a big problem, but becomes more of an issue when associated with corruption (bad institutions). Our hypothesis is that public debt has a different impact on economic growth depending upon the level of corruption. Where corruption is common, public debt might have worse effects than where corruption is a rare phenomenon.

To the best of our knowledge, our paper is the first that treats the effect of public debt on economic growth as a function of corruption and produces results showing the negative effect of corruption on the relationship between public debt and economic growth. Our data cover advanced, developing and underdeveloped countries so that the results might be generalized easily. We also provide the estimation results of various specifications and of sample sections to check the robustness.

\section{Empirical Analysis}

As discussed in the previous section, the main goal of this paper is to investigate whether or not the marginal effect of public debt on economic growth is dependent upon corruption (a proxy for institutional quality). To test this assertion, we provide empirical models, data, and estimation results in this section.

\subsection{Model Specification and Estimation Methodology}

To estimate the effect of corruption on the relationship between public debt and economic growth, we utilize a standard panel growth regression model, adopted in Woo and Kumar [49], except for the interaction term between public debt and corruption. The basic model is expressed as follows:

$$
\begin{aligned}
& \Delta y_{i t}=\beta_{0} \log \left(y_{i t-4}\right)+\beta_{1} \log \left(\text { Debt }_{i t-4}\right)+\beta_{2} \text { Corruption }_{i t-4}+ \\
& \beta_{3} \log \left(\text { Debt }_{i t-4}\right) \times \text { Corruption }_{i t-4}+Z^{\prime} X_{i t-4}+\rho_{i}+\tau_{t}+\varepsilon_{i t}
\end{aligned}
$$

where $i$ and $t$ represent the countries included in the analysis and the time periods, respectively $(i=1, \ldots ., 77$ and $t=1990, \ldots ., 2014) . \Delta y_{i t}$ is defined to be $\left[\log \left(y_{i t}\right)-\log \left(y_{i t-4}\right)\right] / 4$, the average growth rate of the real per capita GDP of country $i$ over the period of four years. The initial GDP per capita is controlled for with $\log \left(y_{i t-4}\right) . \log \left(\right.$ Debt $\left._{i t-4}\right)$ and Corruption ${ }_{i t-4}$ are the public debt and the corruption level of country $i$ at the beginning of the period, respectively. $X_{i t-4}$ is a vector of other control variables and $Z^{\prime}$ is a vector of coefficients for those control variables. The remaining variables, $\rho_{i}$ and $\tau_{t}$ are country-specific fixed effect and period-specific fixed effect, respectively. The last term, $\varepsilon_{i t}$, is the idiosyncratic error term.

As implied in Equation (1), the marginal effect of public debt on economic growth is calculated as follows:

$$
\frac{\partial\left(\Delta y_{i t}\right)}{\partial\left(\log \left(\text { Debt }_{i t-4}\right)\right)}=\beta_{1}+\beta_{3} \times \text { Corruption }_{i t-4} \text {. }
$$


The above equation clearly shows that the marginal effect of public debt on economic grow is a function of corruption. Put in other words, the marginal effect is not homogeneous across countries but is dependent upon how corrupt a specific country is. The negative marginal effect of public debt on economic growth seems to worsen in very corrupt countries whereas the magnitude of the negative effect becomes smaller in less corrupt countries. It is also possible that the effect is positive where corruption level is extremely low as expressed in Figure 2.

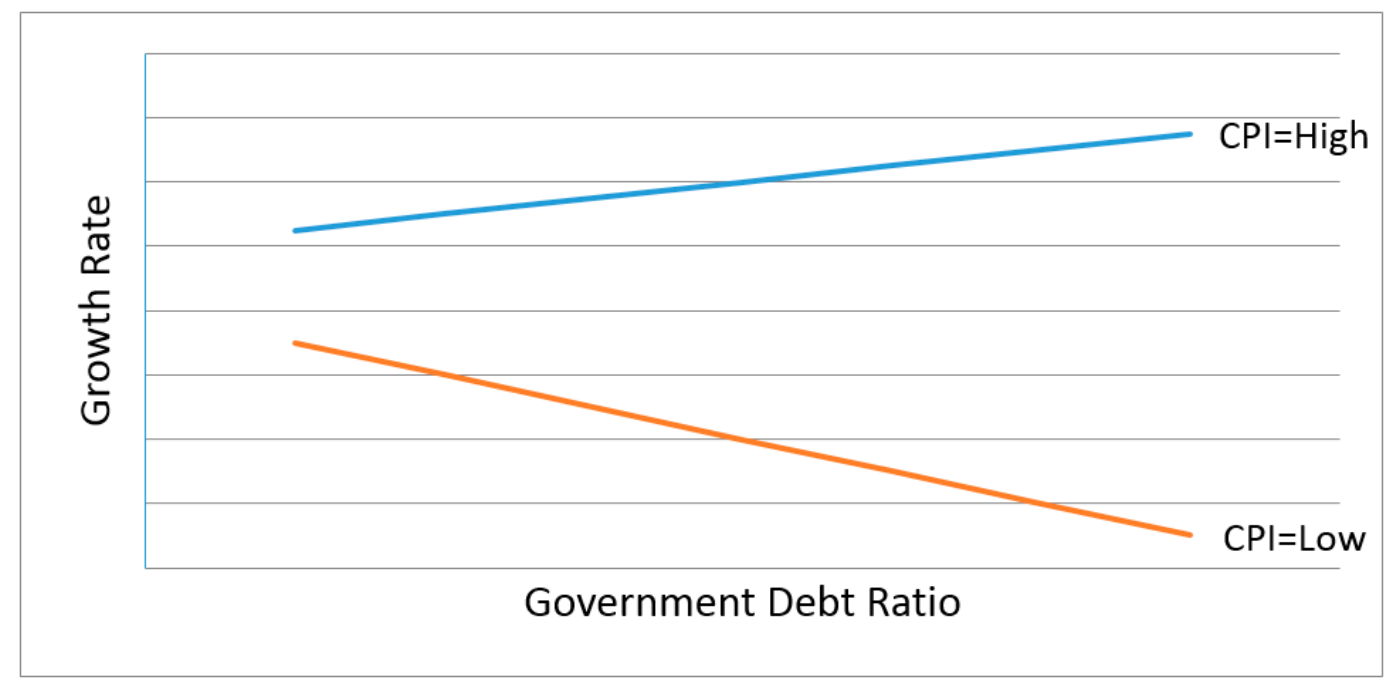

Figure 2. Marginal effect of public debt on growth as a function of corruption (note: CPI is the CORRUPTION PERCEPTIONS INDEX published by Transparency International. A higher number means a lower level of corruption).

Besides its interaction with public debt, it is a well-known fact that corruption can affect economic growth directly. This implies that we need to control for the direct effect of corruption on growth. However, what direction the effect goes has been and is still controversial. Myrdal [104] asserts that if public officials are corrupt, they might use arbitrary power to set up barriers and delays to collect bribes that would not exist otherwise. Krueger [105] also emphasizes the harmful effects of socially inefficient rent-seeking through corrupt trade restriction enforcement. Shleifer and Vishny [106] show that if too much permission is needed to carry out a project, the cost of corruption might rise and slow down economic growth. There are, on the other hand, studies which argue the positive effects of corruption on economic growth. According to Lui [107], the amount of time waiting in queues can be shortened and therefore economic growth is expedited. Klitgaard [108] and Colombatto [109] also emphasize that corruption may result in positive effects on economic growth in some circumstances.

Empirical research is abundant in testing the effects of corruption on economic growth. Many studies report that corruption retards economic growth [68-70,74,110-113]. There are, however, other studies, which state the positive effects of corruption on growth [70,114]. Furthermore, Svensson [115] shows that corruption has no significant effect on economic growth. And some studies aim to separate the effects of corruption on growth according to appropriate variables. Assiotis and Sylwester [116] assume that the effect might differ across democratic and nondemocratic regimes. They conclude that corruption harms economic growth to a larger extent in authoritarian regimes than in democratic countries. The authors support this claim by stating that corruption generates more uncertainty, is more pernicious, or decreases substitutability with other forms of rent-seeking in autocracies. Ugur [117] uses a meta-analysis to estimate the effects of corruption on economic growth, noticing mixed results. It shows that the effect is more adverse if the growth variable is long running, and only low-income countries are used. It is also noticeable that the effect is less adverse when the International Country Risk Guide corruption perceptions index is used. 
Other variables affecting economic growth need to be controlled for. For this purpose, we follow the standard specification, more specifically Woo and Kumar [49]. First, the initial real GDP per capita in each sub-period is controlled for since the convergence hypothesis is emphasized in neoclassical growth models. The second control variable is human capital. Human capital is known to affect economic growth in a positive way in that a high level of human capital stock is likely to attract investors across countries and spur innovative activities as stressed in Grossman et al. [118]. As a proxy for human capital, the log of average years of secondary schooling in a population over age 15 in the initial year of each period is used. According to Sala-i-Martin et al. [119], government size also needs to be controlled for. For this purpose, initial government size of each period is included which is measured by government consumption ratio to GDP. Modigliani et al. [50] also use trade openness as a control variable. Following them, we include the sum of exports and imports as a percentage of GDP. Initial inflation needs to be controlled for. Logarithm of $(1+$ inflation rate $)$ in the first year of each period is used. Finally, $[120,121]$ show that fiscal deficits have negative effects on long-run growth. The initial level of fiscal deficits is also included as a control variable.

As explicitly pointed out in Woo and Kumar [49], there are a number of sources of biases in panel estimations. Each of the estimation techniques has its own merits and weaknesses. For the robustness of estimation results, we use three major estimation tools: pooled OLS, fixed effects models and a GMM dynamic panel regression by Reinhart and Rogoff [1]. The OLS estimation results are likely to be biased and are included just for comparison. We also try to select different sample sizes. Furthermore, averages over five years and ten years are also estimated.

\subsection{Data and Basic Findings}

Transparency International provides a good measure of corruption, the Corruption Perceptions Index (CPI). This index is used in many studies. The CPI is an average of scores from 16 different surveys that measure the perceived levels of corruption, and in this sense, it is an index of indexes. The scale of CPI runs from 0 , most corrupt, to 10, least corrupt. There are other studies that use different measures to estimate the level of corruption; however, the CPI is the most widely used. It should be acknowledged that it has limitations: perception index and possible inconsistency over time. For this reason, we will use another indicator later-the control of corruption of WGI-for robustness.

Table 1 shows that other control variables come mainly from Penn World Table v9.0. More specifically, real GDP per capita, human capital, government size, and trade openness are from Penn World Table. Inflation rates, public debt and deficit are obtained from the World Economic Outlook issued by the IMF. The variable names, definitions, and data sources are summarized in the following table.

Table 1. Variables and data sources.

\begin{tabular}{ccc}
\hline Variable Name & Definition & Source \\
\hline GDP Per Capita & Log of real GDP per capita on the basis of the 2011 price & Penn World Table v9.0 \\
\hline Human Capital & $\begin{array}{c}\text { Log of average years of secondary schooling in the } \\
\text { population over age 15 in the initial year of each period }\end{array}$ & Penn World Table v9.0 \\
\hline Inflation & Logarithm of (1 + inflation rate) & IMF WEO data \\
\hline Government Size & Government consumption ratio to GDP & Penn World Table v9.0 \\
\hline Trade Openness & Sum of export and import as a percentage of GDP & Penn World Table v9.0 \\
\hline Debt & $\begin{array}{c}\text { The ratio of public debt to GDP. Debt is general } \\
\text { government's gross debt. }\end{array}$ & IMF WEO data \\
\hline Deficit & $\begin{array}{c}\text { The ratio of fiscal deficit to GDP, measured by the } \\
\text { difference between government } \\
\text { revenue and expenditure }\end{array}$ & IMF WEO data \\
CPI & $\begin{array}{c}\text { CORRUPTION PERCEPTIONS INDEX published by } \\
\text { Transparency International: the score has been rescaled } \\
\text { in 2012 (from a 10-point scale to a 100-point scale) } \\
\text { The scores from 2012 were converted } \\
\text { to the scale before 2012. }\end{array}$ & Transparency International \\
\hline
\end{tabular}


Table 2 below contains descriptive statistics for the full set of 77 countries used in the analysis. The corruption level variable, the CPI score, runs from 1.1 to 10 . The bigger the score, the less corrupt the country. The mean is 5.202 and the standard deviation is 2.3. It seems that the variation is enough. The ratio of public debt to GDP has a mean of 0.606 . It is noticeable that the gap between the minimum, 0.001 , and the maximum, 2.491 , is very big. Since the standard deviation is 0.377 , the distribution of the ration of public debt to GDP is also very variable. Table A1 in the Appendix A shows correlations between the variables.

Table 2. Descriptive statistics: 77 countries.

\begin{tabular}{ccccc}
\hline Variable & Mean & Std. Dev. & Min & Max \\
\hline GDP per capita & 19,730 & 16,168 & 592 & 75,920 \\
CPI & 5.202 & 2.300 & 1.100 & 10.000 \\
Human capital & 2.680 & 0.648 & 1.126 & 3.734 \\
Inflation & 0.043 & 0.065 & -0.040 & 0.619 \\
Government size & 0.179 & 0.059 & 0.043 & 0.409 \\
Trade openness & 0.674 & 0.596 & 0.077 & 4.615 \\
Deficit & 0.025 & 0.048 & -0.281 & 0.177 \\
Debt & 0.606 & 0.377 & 0.001 & 2.491 \\
\hline
\end{tabular}

Taking a first glance at the effect of corruption on the relationship between public debt and economic growth, we plot a figure as shown in Figure 3. All countries are divided into two groups: one with the CPI above 5.0 and the other below 5.0. A simple relationship between the two variables is expressed with straight lines. As can be easily seen in the figure, there seems to be a difference in the slopes of the simple line plots of public debt and economic growth, as argued in the previous section.

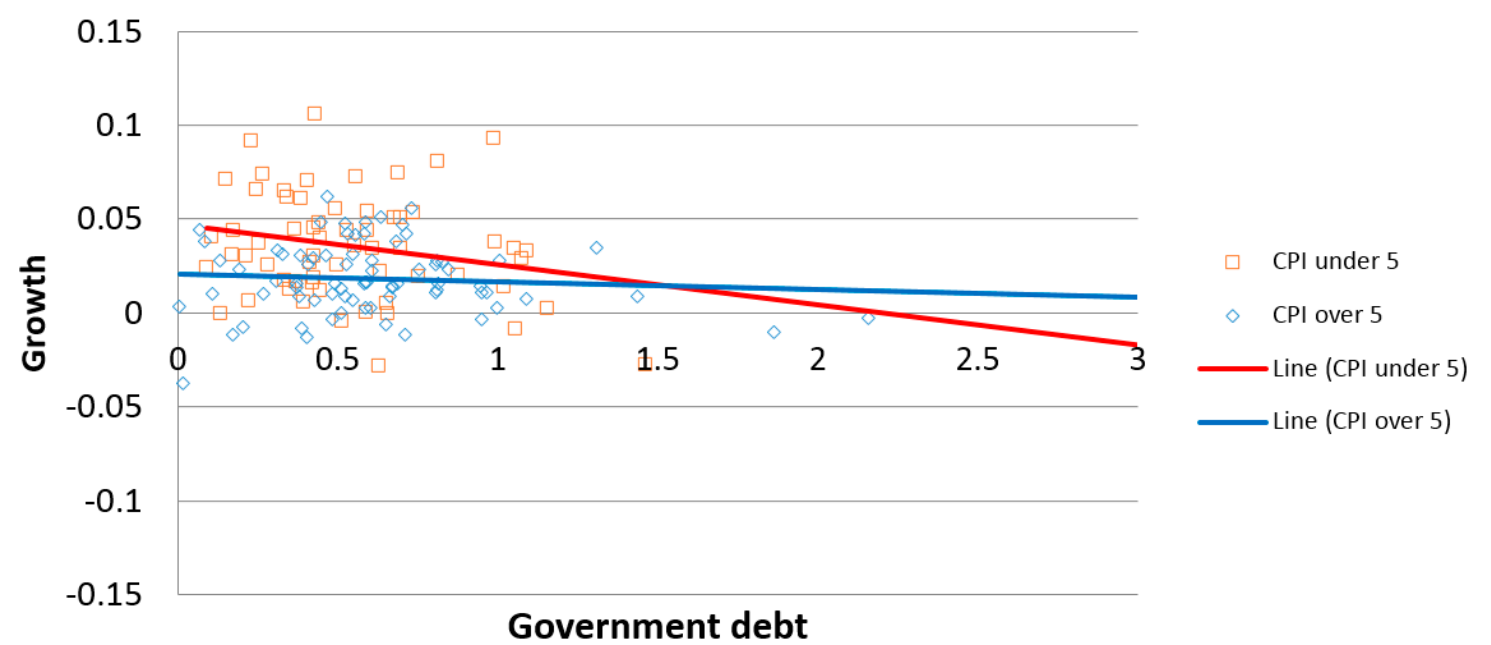

Figure 3. Public debt, corruption, and real GDP growth: actual data.

Table 3 below presents the estimation results for the 77 countries (The list of countries is provided in Table A2 in the Appendix A). The first two columns contain the OLS estimation results, models (1) and (2). Models (3) and (4) show the results estimated with fixed effects models. The last two columns summarize the estimation results with the GMM dynamic panel regression (Arellano-Bond, 1991). Two models were selected for each estimation method: one excludes the CPI as an independent variable and the other includes the index. This is to see whether corruption affects economic growth directly or indirectly through public debt only. 
Table 3. Estimation results: five-year period and 77 countries.

\begin{tabular}{|c|c|c|c|c|c|c|}
\hline \multirow{2}{*}{ Variables } & Model (1) & Model (2) & Model (3) & Model (4) & Model (5) & Model (6) \\
\hline & OLS & OLS & Fixed Effect & Fixed Effect & GMM & GMM \\
\hline Initial GDP & $\begin{array}{c}-0.0207^{* * *} \\
(0.00388)\end{array}$ & $\begin{array}{c}-0.0201 * * * \\
(0.00392)\end{array}$ & $\begin{array}{c}-0.0997 * * * \\
(0.0117)\end{array}$ & $\begin{array}{c}-0.101^{* * *} \\
(0.0116)\end{array}$ & $\begin{array}{c}-0.136^{* * *} \\
(0.0157)\end{array}$ & $\begin{array}{c}-0.137^{* * *} \\
(0.0157)\end{array}$ \\
\hline Human Capital & $\begin{array}{c}0.0202 * * * \\
(0.00578)\end{array}$ & $\begin{array}{c}0.0211^{* * *} \\
(0.00583)\end{array}$ & $\begin{array}{c}0.0832 * * * \\
(0.0220)\end{array}$ & $\begin{array}{c}0.0860 * * * \\
(0.0219)\end{array}$ & $\begin{array}{c}0.0932 * * * \\
(0.0272)\end{array}$ & $\begin{array}{c}0.0948^{* * *} \\
(0.0273)\end{array}$ \\
\hline Inflation & $\begin{array}{l}0.00180 \\
(0.0413) \\
\end{array}$ & $\begin{array}{c}-0.00408 \\
(0.0416)\end{array}$ & $\begin{array}{c}-0.127^{* * *} \\
(0.0420)\end{array}$ & $\begin{array}{c}-0.110 \text { ** } \\
(0.0431)\end{array}$ & $\begin{array}{l}-0.0512 \\
(0.0538)\end{array}$ & $\begin{array}{l}-0.0398 \\
(0.0555)\end{array}$ \\
\hline Government Size & $\begin{array}{c}-0.00742 \\
(0.0361)\end{array}$ & $\begin{array}{l}-0.0131 \\
(0.0364)\end{array}$ & $\begin{array}{c}-0.357^{* * *} \\
(0.0614)\end{array}$ & $\begin{array}{c}-0.344^{* * *} \\
(0.0616)\end{array}$ & $\begin{array}{c}-0.267^{* * *} \\
(0.0766)\end{array}$ & $\begin{array}{c}-0.264^{* * *} \\
(0.0768)\end{array}$ \\
\hline Trade Openness & $\begin{array}{l}0.00629 * \\
(0.00355) \\
\end{array}$ & $\begin{array}{l}0.00690 * \\
(0.00359)\end{array}$ & $\begin{array}{c}0.0261^{* * *} \\
(0.00712)\end{array}$ & $\begin{array}{c}0.0250 * * * \\
(0.00712)\end{array}$ & $\begin{array}{c}0.0644 * * * \\
(0.0139)\end{array}$ & $\begin{array}{c}0.0643 * * * \\
(0.0139)\end{array}$ \\
\hline Deficit & $\begin{array}{l}-0.0537 \\
(0.0361) \\
\end{array}$ & $\begin{array}{l}-0.0546 \\
(0.0360) \\
\end{array}$ & $\begin{array}{c}0.0264 \\
(0.0485) \\
\end{array}$ & $\begin{array}{c}0.0377 \\
(0.0488) \\
\end{array}$ & $\begin{array}{c}0.0567 \\
(0.0653) \\
\end{array}$ & $\begin{array}{c}0.0645 \\
(0.0658) \\
\end{array}$ \\
\hline Debt & $\begin{array}{c}-0.00314 \\
(0.0124) \\
\end{array}$ & $\begin{array}{l}-0.0135 \\
(0.0155) \\
\end{array}$ & $\begin{array}{c}-0.0300 * \\
(0.0179)\end{array}$ & $\begin{array}{l}-0.0149 \\
(0.0201) \\
\end{array}$ & $\begin{array}{c}-0.0542 * * \\
(0.0229)\end{array}$ & $\begin{array}{c}-0.0443 * \\
(0.0251)\end{array}$ \\
\hline CPI & $\begin{array}{l}- \\
- \\
\end{array}$ & $\begin{array}{l}-0.00209 \\
(0.00189) \\
\end{array}$ & $\begin{array}{l}- \\
-\end{array}$ & $\begin{array}{c}0.00712 \\
(0.00439) \\
\end{array}$ & $\begin{array}{l}- \\
-\end{array}$ & $\begin{array}{c}0.00449 \\
(0.00505) \\
\end{array}$ \\
\hline Debt $^{*}$ CPI & $\begin{array}{l}0.000558 \\
(0.00206)\end{array}$ & $\begin{array}{c}0.00259 \\
(0.00276)\end{array}$ & $\begin{array}{c}0.00678^{* *} \\
(0.00317)\end{array}$ & $\begin{array}{c}0.00322 \\
(0.00384)\end{array}$ & $\begin{array}{l}0.0101^{* *} \\
(0.00474)\end{array}$ & $\begin{array}{c}0.00783 \\
(0.00541)\end{array}$ \\
\hline Constant & $\begin{array}{c}0.167^{* * *} \\
(0.0297)\end{array}$ & $\begin{array}{c}0.171^{* * * *} \\
(0.0299)\end{array}$ & $\begin{array}{c}0.796^{* * *} \\
(0.0823)\end{array}$ & $\begin{array}{c}0.759 * * * \\
(0.0850)\end{array}$ & $\begin{array}{c}1.067 * * * \\
(0.118)\end{array}$ & $\begin{array}{c}1.044^{* * *} \\
(0.122)\end{array}$ \\
\hline Observations & 258 & 258 & 258 & 258 & 144 & 144 \\
\hline R-squared & 0.133 & 0.137 & 0.468 & 0.476 & & \\
\hline $\operatorname{AR}(1)$ & & & & & 0.4113 & 0.3754 \\
\hline Sargan Test & & & & & 0.3542 & 0.4326 \\
\hline
\end{tabular}

Since the OLS estimation results are likely to be biased and are included just for comparison, we focus on the fixed effects models and GMM estimations. Public debt is estimated to have a negative effect on economic growth regardless of the model used. All the coefficients are statistically significant at the 0.10 level except for OLS and model (4). Unlike the previous studies, corruption does not seem to influence economic growth because the CPI itself is not statistically significant in any of the models. Other control variables are estimated to be predictable as in previous research.

The main focus of this paper as discussed in the previous section is the coefficient on the interaction variable between debt and corruption, Debt ${ }^{*}$ CPI. In model (3), the estimate of the coefficient is 0.00678 whereas that of the debt variable is -0.03 . This implies that the effect of public debt on economic growth is a function of corruption. Even though public debt itself has a negative effect, the overall effect is determined by Equation (2). If we accept the estimates in model (3), the marginal effect of public debt on economic growth is -0.03 when the CPI is 0 . The marginal effect increases, however, as the CPI score moves up since the interaction term has a coefficient of 0.00678 . For instance, the effect increases to 0.378 when the CPI is 10 . The threshold from negative to positive is 4.4248 . If we take the estimation results of model (5), the threshold becomes 5.3663 .

Table 4 summarizes the estimation results with only 38 countries (more advanced countries), following Woo and Kumar (2015). As seen in the table, the basic results are similar to those with 77 countries even if the magnitude and statistical significance levels are slightly different. The threshold is 7.1611 in model (3) and 8.2132 in model (5). This implies that the CPI should be bigger to make public debt have a positive effect on economic growth compared to the case of all 77 countries.

Based on the estimation results above, we can plot a figure showing the marginal effect of public debt on economic growth, which is dependent upon corruption. If we take the estimates in model (3) in the table above, the marginal effects are different across countries since each has a 
different level of corruption. Figure 4 shows three different cases of CPI scores: 1.0, 5.0 and 9.0. When the CPI score is 1 , the marginal effect becomes -0.03863 based on the calculation: slope $=-0.0449+0.00627{ }^{*} \mathrm{CPI}$. In the meantime, the slopes are -0.01355 and 0.01153 when the CPI scores are 5 and 9 , respectively.

Table 4. Estimation results: five-year period and 38 countries.

\begin{tabular}{ccccccc}
\hline \multirow{2}{*}{ Variables } & Model (1) & Model (2) & Model (3) & Model (4) & Model (5) & Model (6) \\
\cline { 2 - 7 } & OLS & OLS & Fixed Effect & Fixed Effect & GMM & GMM \\
\hline \multirow{2}{*}{ Initial GDP } & $-0.0214^{* * *}$ & $-0.0188^{* * *}$ & $-0.0740^{* * *}$ & $-0.0734^{* * *}$ & $-0.0993^{* * *}$ & $-0.0921^{* * *}$ \\
& $(0.00478)$ & $(0.00523)$ & $(0.0146)$ & $(0.0148)$ & $(0.0220)$ & $(0.0222)$ \\
\hline \multirow{2}{*}{ Human Capital } & 0.0107 & 0.00995 & $0.0994^{* * *}$ & $0.0990^{* * *}$ & $0.135^{* * *}$ & $0.132^{* * *}$ \\
& $(0.00649)$ & $(0.00650)$ & $(0.0271)$ & $(0.0272)$ & $(0.0331)$ & $(0.0329)$ \\
\hline \multirow{2}{*}{ Inflation } & -0.0438 & -0.0470 & $-0.115^{* *}$ & $-0.117^{* *}$ & -0.0811 & $-0.101^{*}$ \\
& $(0.0413)$ & $(0.0413)$ & $(0.0448)$ & $(0.0455)$ & $(0.0566)$ & $(0.0575)$ \\
\hline \multirow{2}{*}{ Government Size } & -0.00341 & -0.0142 & $-0.393^{* * * *}$ & $-0.393^{* * *}$ & $-0.248^{* *}$ & $-0.249^{* *}$ \\
& $(0.0417)$ & $(0.0425)$ & $(0.0819)$ & $(0.0823)$ & $(0.107)$ & $(0.106)$ \\
\hline \multirow{2}{*}{ Trade Openness } & -0.00270 & -0.00215 & 0.00209 & 0.00219 & 0.0120 & 0.00814 \\
& $(0.00401)$ & $(0.00403)$ & $(0.0116)$ & $(0.0116)$ & $(0.0151)$ & $(0.0150)$ \\
\hline \multirow{2}{*}{ Deficit } & 0.0841 & 0.0892 & $0.139 * *$ & $0.137^{* * *}$ & -0.0271 & -0.0354 \\
& $(0.0612)$ & $(0.0612)$ & $(0.0643)$ & $(0.0649)$ & $(0.0924)$ & $(0.0926)$ \\
\hline \multirow{2}{*}{ Debt } & -0.0226 & $-0.0415^{*}$ & $-0.0449^{*}$ & -0.0501 & $-0.0786^{*}$ & $-0.105^{* *}$ \\
& $(0.0148)$ & $(0.0213)$ & $(0.0269)$ & $(0.0326)$ & $(0.0403)$ & $(0.0432)$ \\
\hline \multirow{2}{*}{ CPI } & - & -0.00282 & - & -0.00150 & - & -0.00805 \\
& - & $(0.00228)$ & - & $(0.00531)$ & - & $(0.00621)$ \\
\hline \multirow{2}{*}{ Debt*PI } & 0.00168 & 0.00464 & $0.00627^{*}$ & 0.00719 & $0.00957^{*}$ & $0.0148^{* *}$ \\
\hline \multirow{2}{*}{ Constant } & $(0.00212)$ & $(0.00319)$ & $(0.00341)$ & $(0.00473)$ & $(0.00573)$ & $(0.00658)$ \\
\hline Observations & $0.214^{* * *}$ & $0.209^{* * *}$ & $0.534^{* * *}$ & $0.539^{* * *}$ & $0.660^{* * *}$ & $0.647^{* * *}$ \\
\hline R-squared & $(0.0375)$ & $(0.0377)$ & $(0.101)$ & $(0.103)$ & $(0.173)$ & $(0.171)$ \\
\hline AR(1) & 137 & 137 & 137 & 137 & 73 & 73 \\
\hline
\end{tabular}

Standard errors in parentheses; ${ }^{* * *} p<0.01,{ }^{* *} p<0.05,{ }^{*} p<0.1$.

As shown above, the magnitude of the marginal effect is quite meaningful since it changes across countries. Depending on the level of corruption, the marginal effect can be positive or negative. If the estimated coefficients were not meaningful in magnitude, we would end up with similar marginal effects across countries.

The results above are sharply contrasted to those in Jalles [5]. In the estimation results of Jalles [5], the estimate of the interaction term between public debt and corruption turned out to be negative. This implies that corruption has a positive moderating effect on the relationship between public debt and economic growth, which contradicts the theoretical prediction. As discussed in Section 2 above, the moderating effect of corruption should be negative in any case. The results shown in Tables 3 and 4 though conform to the theoretical implication. The interaction term between debt and the CPI was estimated to have a positive sign regardless of the models.

Our results are different from the previous studies in the direct effect of corruption on economic growth. As explained in Section 2, the majority of the literature supports a negative effect of corruption on the economy. Tables 3 and 4 show, however, that the direct effect is not statistically significant. The estimates for CPI are not statistically significant even at the 0.10 level.

We also tried to test the non-linearity of the effect of debt on economic growth. We, however, came up with no evidence of non-linearity. In almost all of the models, the square term of debt has been estimated to be insignificant. This implies that there does not seem to be a threshold in the effect of debt on economic growth as asserted in several previous studies. 


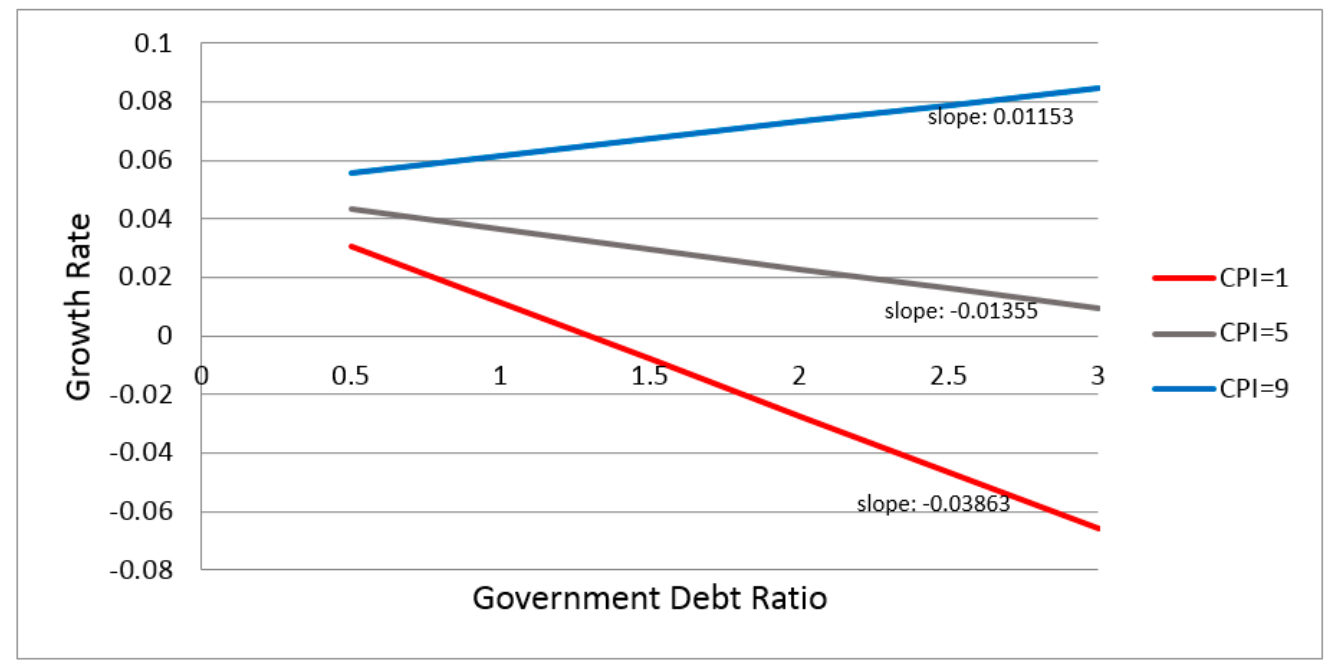

Figure 4. Public debt, corruption, and real GDP growth: based on estimation results.

\section{Robustness Check}

In this section, we investigate the robustness of the estimation results. For this purpose, a five-year average model is estimated. Put in other words, every variable is averaged over a five-year period and Equation (1) is re-estimated in the same way as in the previous subsection. In addition, a ten-year average model is estimated. We also vary the sample size. That is, the same models are estimated for different groups of countries: 38 countries, 46 countries as well as 77 countries. The list of countries for each group is provided in the Appendix A. The first group consists of advanced countries and the second includes advanced and developing countries.

Table A3 in the Appendix A presents the estimation results for the five-year average model with 38 countries. As can be easily seen, the results are similar to the case of the five-year period model shown in the previous table. However, the magnitude and statistical significance levels vary. Most prominent differences occur in the estimates of the CPI. More specifically, the CPI itself is statistically significant unlike in the five-year period models.

From the estimates in the columns of models (3) and (5), we can find that the key variables, debt and Debt ${ }^{*} \mathrm{CPI}$, are estimated to be more significant than in the case of five-year period models. This implies that the five-year average model strengthens the hypothesis that the marginal effect of public debt on economic growth is a function of corruption. As done above, we can calculate the threshold separating the negative and positive effects of public debt on economic growth. The thresholds are 8.2059 and 8.9730 , respectively. It is noticeable that these are very similar to the thresholds computed above, 7.1611 and 8.2132.

Tables A4 and A5 show the estimation results of the five-year average model with 46 and 77 countries. There are no noticeable changes in the signs and statistical significances across the estimated coefficients. We can say the estimation results are robust to the changes in models (five-year average model) and same size.

Tables A6-A8 in the Appendix A summarize the estimation results with the ten-year average model. The model intends to capture a more long-run relationship among variables. The GMM method by Arellano-Bond [4] has been dropped since the time span to implement dynamic panel estimation is insufficient in the ten-year average model. Similar to the case of the five-year average model, the pooled OLS regression results in significant coefficients for the debt variable and the interaction term between debt and corruption except for the 77 country models.

If we accept the estimates from column (3), the threshold becomes 7.9191, which is approximate to the five-year case. This implies that the estimation results seem to be robust in the long run. As shown above, the estimation results are very robust to models and sample selections. Except for the pooled OLS, the results are also robust to estimation methods. We can therefore conclude that empirical 
data supports our hypothesis. The marginal effect of public debt on economic growth seems to be dependent on the level of corruption of each country.

We also re-estimated the models with the control of corruption of WGI for the robustness of the results. Tables A9-A16 in the Appendix A show the estimation results. As seen in the tables, there are no big differences in the results, especially in the estimates of the interaction term between debt and corruption. The major difference lies in the magnitudes of the estimate for the interaction term, which is driven by the difference in the scale of the two indicators.

\section{Conclusions}

The vast array of literature represents the interest in the relationship between public debt and economic growth. It is hard to find, however, research addressing the role of corruption in these two variables. Noticing this vacancy in the literature, we aimed to investigate the effect of corruption on the relationship between public debt and economic growth. We included the interaction term between public debt and corruption to test our hypothesis that the marginal effect of public debt on growth is a function of corruption.

The pooled ordinary least squares (OLS), fixed effects models and the dynamic panel Gaussian mixture models (GMM) of Arellano-Bond [4] are estimated using data of 77 countries from 1990 to 2014. The empirical results show that the interaction term between public debt and corruption is statistically significant. This confirms the hypothesis that the effect of public debt on economic growth is a function of corruption. Even if the threshold differentiating the sign of the marginal effect is dependent upon which model is selected, it can be concluded that within a highly transparent-not corrupt—country, public debt enhances economic growth and vice versa.

To test the robustness of the estimation results, five-year average models and ten-year average models are estimated. We also gave variations in the sample size. That is, the same models are estimated for different groups of countries: 38 countries, 46 countries as well as 77 countries. We conclude that the estimation results are robust to the changes in models and in same size.

The main policy implication from the findings is that institutional quality, i.e., corruption, can play a very important role in determining the effect of public debt policies. To alleviate the negative effect of public debt on economic growth and to maintain economic sustainability, governments and international organizations should strive to enhance the quality of their institutions in order to maximize revenue utilization in the long run.

Author Contributions: The authors equally contributed to the paper; Sangheon Kim and Eunji Kim developed the idea and designed the paper; Yoonhee Ha, Eunji Kim and Sangheon Kim analyzed the data and completed the first draft; All the authors reviewed and revised the final version of paper.

Conflicts of Interest: The authors declare no conflict of interest.

\section{Appendix A}

Table A1. Correlation table.

\begin{tabular}{|c|c|c|c|c|c|c|c|c|c|}
\hline & Growth & $\begin{array}{l}\text { Initial } \\
\text { GDP }\end{array}$ & $\begin{array}{l}\text { Human } \\
\text { Capital }\end{array}$ & Inflation & $\begin{array}{l}\text { Governmen } \\
\text { Size }\end{array}$ & $\begin{array}{l}\text { it Trade } \\
\text { Openness }\end{array}$ & Deficit & Debt & CPI \\
\hline Growth & 1 & & & & & & & & \\
\hline Initial GDP & -0.220 & 1 & & & & & & & \\
\hline Human Capital & -0.0793 & 0.822 & 1 & & & & & & \\
\hline Inflation & -0.114 & -0.271 & -0.252 & 1 & & & & & \\
\hline $\begin{array}{c}\text { Government } \\
\text { Size }\end{array}$ & 0.00540 & -0.0317 & 0.166 & 0.149 & 1 & & & & \\
\hline $\begin{array}{c}\text { Trade } \\
\text { Openness }\end{array}$ & 0.0285 & 0.456 & 0.345 & -0.244 & -0.0599 & 1 & & & \\
\hline Deficit & -0.0131 & -0.194 & -0.00340 & 0.0280 & 0.0982 & -0.227 & 1 & & \\
\hline Debt & 0.0518 & -0.210 & -0.176 & 0.111 & 0.115 & -0.0382 & 0.172 & 1 & \\
\hline CPI & -0.124 & 0.769 & 0.672 & -0.336 & -0.0905 & 0.513 & -0.190 & -0.0365 & 1 \\
\hline WGI & -0.297 & 0.768 & 0.667 & -0.333 & -0.0567 & 0.552 & -0.131 & -0.0704 & 0.979 \\
\hline
\end{tabular}


Table A2. List of countries.

\begin{tabular}{|c|c|c|}
\hline \multicolumn{3}{|c|}{ List of 38 Countries } \\
\hline Australia & Germany & Poland \\
\hline Austria & Greece & Portugal \\
\hline Belgium & Hungary & Republic of Korea \\
\hline Brazil & India & Russian Federation \\
\hline Canada & Indonesia & Slovakia \\
\hline Chile & Italy & South Africa \\
\hline China & Japan & Spain \\
\hline China, Hong Kong SAR & Malaysia & Sweden \\
\hline Colombia & Mexico & Switzerland \\
\hline Czech Republic & Netherlands & Turkey \\
\hline Denmark & Pakistan & United Kingdom \\
\hline Egypt & Peru & United States \\
\hline France & Philippines & \\
\hline \multicolumn{3}{|c|}{ List of 46 Countries: $38+$ Countries Below } \\
\hline Finland & Israel & Norway \\
\hline Iceland & Jordan & Singapore \\
\hline Ireland & New Zealand & \\
\hline \multicolumn{3}{|c|}{ List of 77 Countries: 46 Countries + Below } \\
\hline Bulgaria & Kuwait & Senegal \\
\hline Bolivia (Plurinational State of) & Sri Lanka & Slovenia \\
\hline Barbados & Lesotho & Swaziland \\
\hline Costa Rica & Mozambique & Syrian Arab Republic \\
\hline Cyprus & Mauritania & Togo \\
\hline Ecuador & Mauritius & Trinidad and Tobago \\
\hline Gambia & Nicaragua & Tunisia \\
\hline Honduras & Panama & Uganda \\
\hline Croatia & Romania & Uruguay \\
\hline Iran (Islamic Republic of) & Rwanda & \\
\hline Jamaica & Sudan (Former) & \\
\hline
\end{tabular}

Estimation Results for Robustness Check.

Table A3. Estimation results: five-year average and 38 countries.

\begin{tabular}{ccccccc}
\hline \multirow{2}{*}{ Variables } & Model (1) & Model (2) & Model (3) & Model (4) & Model (5) & Model (6) \\
\cline { 2 - 7 } & OLS & OLS & Fixed Effect & Fixed Effect & GMM & GMM \\
\hline \multirow{2}{*}{ Initial GDP } & $-0.0197^{* * *}$ & $-0.0155^{* * *}$ & $-0.0759^{* * *}$ & $-0.0732^{* * *}$ & $-0.0936^{* * *}$ & $-0.0800^{* * *}$ \\
& $(0.00475)$ & $(0.00534)$ & $(0.0140)$ & $(0.0141)$ & $(0.0203)$ & $(0.0200)$ \\
\hline Human & 0.00824 & 0.00652 & $0.128^{* * *}$ & $0.128^{* * *}$ & $0.152^{* * *}$ & $0.144^{* * * *}$ \\
Capital & $(0.00661)$ & $(0.00664)$ & $(0.0285)$ & $(0.0284)$ & $(0.0328)$ & $(0.0317)$ \\
\hline \multirow{2}{*}{ Inflation } & -0.0511 & -0.0640 & -0.105 & -0.109 & -0.0396 & -0.0655 \\
& $(0.0607)$ & $(0.0607)$ & $(0.0723)$ & $(0.0722)$ & $(0.0889)$ & $(0.0863)$ \\
\hline Government & 0.0117 & -0.00328 & $-0.454^{* * *}$ & $-0.455^{* * *}$ & $-0.253^{*}$ & $-0.255^{* *}$ \\
Size & $(0.0421)$ & $(0.0428)$ & $(0.0947)$ & $(0.0943)$ & $(0.132)$ & $(0.128)$ \\
\hline Trade & -0.00401 & -0.00335 & -0.00369 & -0.00375 & 0.00611 & 0.000569 \\
Openness & $(0.00374)$ & $(0.00374)$ & $(0.0109)$ & $(0.0109)$ & $(0.0136)$ & $(0.0133)$ \\
\hline \multirow{2}{*}{ Deficit } & 0.0533 & 0.0746 & 0.0343 & -0.00495 & -0.0588 & -0.114 \\
& $(0.0882)$ & $(0.0885)$ & $(0.120)$ & $(0.123)$ & $(0.138)$ & $(0.139)$ \\
\hline \multirow{2}{*}{ Debt } & $-0.0291^{*}$ & $-0.0567^{* *}$ & $-0.0837^{* * *}$ & $-0.112^{* * *}$ & $-0.166^{* * *}$ & $-0.210^{* * *}$ \\
& $(0.0158)$ & $(0.0226)$ & $(0.0277)$ & $(0.0350)$ & $(0.0380)$ & $(0.0411)$ \\
\hline \multirow{2}{*}{ CPI } & - & $-0.00387^{*}$ & - & -0.00713 & - & $-0.0123^{* *}$ \\
& - & $(0.00228)$ & - & $(0.00545)$ & - & $(0.00574)$ \\
\hline \multirow{2}{*}{ Debt*CPI } & 0.00239 & $0.00650^{* *}$ & $0.0102^{* * *}$ & $0.0149^{* * *}$ & $0.0185^{* * *}$ & $0.0268^{* * *}$ \\
& $(0.00217)$ & $(0.00324)$ & $(0.00350)$ & $(0.00502)$ & $(0.00545)$ & $(0.00616)$ \\
\hline \multirow{2}{*}{ Constant } & $0.206^{* * *}$ & $0.195^{* * *}$ & $0.492^{* * *}$ & $0.509^{* * *}$ & $0.575^{* * *}$ & $0.543^{* * * *}$ \\
& $(0.0372)$ & $(0.0374)$ & $(0.0948)$ & $(0.0953)$ & $(0.153)$ & $(0.148)$ \\
\hline Observations & 137 & 137 & 137 & 137 & 73 & 73 \\
\hline$R$-squared & 0.287 & 0.303 & 0.398 & 0.410 & & \\
\hline & & & & & &
\end{tabular}


Table A4. Estimation results: five-year average and 46 countries.

\begin{tabular}{ccccccc}
\hline \multirow{2}{*}{ Variables } & Model (1) & Model (2) & Model (3) & Model (4) & Model (5) & Model (6) \\
\cline { 2 - 7 } & OLS & OLS & Fixed Effect & Fixed Effect & GMM & GMM \\
\hline \multirow{2}{*}{ Initial GDP } & $-0.0253^{* * *}$ & $-0.0235^{* * *}$ & $-0.0906^{* * *}$ & $-0.0894^{* * *}$ & $-0.119^{* * *}$ & $-0.111^{* * *}$ \\
& $(0.00464)$ & $(0.00513)$ & $(0.0121)$ & $(0.0123)$ & $(0.0202)$ & $(0.0205)$ \\
\hline Human & 0.00681 & 0.00593 & $0.0984^{* * *}$ & $0.0966^{* * *}$ & $0.140^{* * *}$ & $0.130^{* * *}$ \\
Capital & $(0.00671)$ & $(0.00680)$ & $(0.0237)$ & $(0.0239)$ & $(0.0296)$ & $(0.0298)$ \\
\hline \multirow{2}{*}{ Inflation } & -0.0166 & -0.0263 & -0.119 & $-0.125^{*}$ & -0.0311 & -0.0493 \\
& $(0.0649)$ & $(0.0660)$ & $(0.0722)$ & $(0.0729)$ & $(0.0974)$ & $(0.0964)$ \\
\hline Government & -0.0233 & -0.0230 & $-0.433^{* * *}$ & $-0.431^{* * *}$ & $-0.363^{* * *}$ & $-0.338^{* * *}$ \\
Size & $(0.0411)$ & $(0.0411)$ & $(0.0783)$ & $(0.0786)$ & $(0.127)$ & $(0.126)$ \\
\hline Trade & 0.00419 & 0.00412 & $0.0251^{* * *}$ & $0.0255^{* * *}$ & $0.0239^{*}$ & $0.0219^{*}$ \\
Openness & $(0.00332)$ & $(0.00333)$ & $(0.00876)$ & $(0.00881)$ & $(0.0134)$ & $(0.0132)$ \\
\hline \multirow{2}{*}{ Deficit } & -0.0358 & -0.0375 & 0.0676 & 0.0551 & 0.106 & 0.0613 \\
& $(0.0626)$ & $(0.0627)$ & $(0.0918)$ & $(0.0940)$ & $(0.126)$ & $(0.130)$ \\
\hline \multirow{2}{*}{ Debt } & $-0.0324^{* *}$ & $-0.0451^{* *}$ & $-0.0996^{* * *}$ & $-0.114^{* * *}$ & $-0.187^{* * *}$ & $-0.224^{* * *}$ \\
& $(0.0158)$ & $(0.0220)$ & $(0.0287)$ & $(0.0366)$ & $(0.0432)$ & $(0.0477)$ \\
\hline \multirow{2}{*}{ CPI } & - & -0.00175 & - & -0.00341 & - & -0.00989 \\
& - & $(0.00210)$ & - & $(0.00519)$ & - & $(0.00612)$ \\
\hline \multirow{2}{*}{ Debt*CPI } & $0.00419^{* *}$ & $0.00609^{*}$ & $0.0116^{* * *}$ & $0.0139^{* * *}$ & $0.0220^{* * *}$ & $0.0280^{* * *}$ \\
& $(0.00222)$ & $(0.00319)$ & $(0.00368)$ & $(0.00510)$ & $(0.00602)$ & $(0.00690)$ \\
\hline \multirow{2}{*}{ Constant } & $0.262^{* * *}$ & $0.259^{* * *}$ & $0.704^{* * *}$ & $0.720^{* * *}$ & $0.864^{* * * *}$ & $0.872^{* * *}$ \\
& $(0.0367)$ & $(0.0370)$ & $(0.0808)$ & $(0.0842)$ & $(0.152)$ & $(0.151)$ \\
\hline Observations & 168 & 168 & 168 & 168 & 89 & 89 \\
\hline$R$-squared & 0.260 & 0.263 & 0.501 & 0.503 & & \\
\hline & & & & & &
\end{tabular}

Table A5. Estimation results: five-year average and 77 countries.

\begin{tabular}{ccccccc}
\hline \multirow{2}{*}{ Variables } & Model (1) & Model (2) & Model (3) & Model (4) & Model (5) & Model (6) \\
\cline { 2 - 7 } & OLS & OLS & Fixed Effect & Fixed Effect & GMM & GMM \\
\hline \multirow{2}{*}{ Initial GDP } & $-0.0207^{* * *}$ & $-0.0202^{* * *}$ & $-0.0968^{* * *}$ & $-0.0978^{* * *}$ & $-0.128^{* * *}$ & $-0.130^{* * *}$ \\
& $(0.00382)$ & $(0.00390)$ & $(0.0113)$ & $(0.0113)$ & $(0.0174)$ & $(0.0172)$ \\
\hline Human & $0.0220^{* * *}$ & $0.0224^{* * *}$ & $0.0849^{* * *}$ & $0.0882^{* * *}$ & $0.107^{* * *}$ & $0.111^{* * *}$ \\
Capital & $(0.00583)$ & $(0.00585)$ & $(0.0222)$ & $(0.0222)$ & $(0.0285)$ & $(0.0284)$ \\
\hline \multirow{2}{*}{ Inflation } & 0.0223 & 0.0144 & $-0.128^{* *}$ & -0.0999 & -0.0879 & -0.0504 \\
& $(0.0547)$ & $(0.0558)$ & $(0.0606)$ & $(0.0629)$ & $(0.0763)$ & $(0.0798)$ \\
\hline Government & -0.00844 & -0.0113 & $-0.379^{* * *}$ & $-0.364^{* * *}$ & $-0.321^{* * *}$ & $-0.308^{* * *}$ \\
Size & $(0.0373)$ & $(0.0375)$ & $(0.0722)$ & $(0.0725)$ & $(0.100)$ & $(0.100)$ \\
\hline Trade & 0.00226 & 0.00265 & $0.0264^{* * *}$ & $0.0253^{* * *}$ & $0.0341^{* *}$ & $0.0337^{* *}$ \\
Openness & $(0.00364)$ & $(0.00368)$ & $(0.00964)$ & $(0.00963)$ & $(0.0148)$ & $(0.0147)$ \\
\hline \multirow{2}{*}{ Deficit } & $-0.0835^{* *}$ & $-0.0822^{*}$ & 0.0313 & 0.0463 & 0.0425 & 0.0541 \\
& $(0.0461)$ & $(0.0462)$ & $(0.0862)$ & $(0.0863)$ & $(0.111)$ & $(0.111)$ \\
\hline \multirow{2}{*}{ Debt } & -0.00626 & -0.0135 & $-0.0494^{* *}$ & -0.0321 & $-0.0672^{* *}$ & $-0.0514^{*}$ \\
& $(0.0129)$ & $(0.0162)$ & $(0.0209)$ & $(0.0235)$ & $(0.0285)$ & $(0.0303)$ \\
\hline \multirow{2}{*}{ CPI } & - & -0.00138 & - & 0.00706 & - & 0.00793 \\
& - & $(0.00186)$ & - & $(0.00445)$ & - & $(0.00517)$ \\
\hline \multirow{2}{*}{ Debt*CPI } & 0.000463 & 0.00179 & $0.00599^{*}$ & 0.00243 & 0.00686 & 0.00337 \\
& $(0.00206)$ & $(0.00273)$ & $(0.00341)$ & $(0.00407)$ & $(0.00522)$ & $(0.00569)$ \\
\hline \multirow{2}{*}{ Constant } & $0.167^{* * *}$ & $0.169^{* * *}$ & $0.777^{* * *}$ & $0.737^{* * *}$ & $1.005^{* * *}$ & $0.967^{* * *}$ \\
& $(0.0284)$ & $(0.0286)$ & $(0.0781)$ & $(0.0817)$ & $(0.125)$ & $(0.128)$ \\
\hline Observations & 257 & 257 & 257 & 257 & 143 & 143 \\
\hline$R$-squared & 0.143 & 0.145 & 0.406 & 0.415 & & \\
\hline & & & & &
\end{tabular}


Table A6. Estimation results: ten-year average and 38 countries.

\begin{tabular}{|c|c|c|c|c|}
\hline \multirow{2}{*}{ Variables } & Model (1) & Model (2) & Model (3) & Model (4) \\
\hline & OLS & OLS & Fixed Effect & Fixed Effect \\
\hline Initial GDP & $\begin{array}{l}0.717^{* * *} \\
(0.0507)\end{array}$ & $\begin{array}{l}0.740 * * * \\
(0.0566)\end{array}$ & $\begin{array}{c}0.598^{* * *} \\
(0.166)\end{array}$ & $\begin{array}{c}0.613^{* * *} \\
(0.172)\end{array}$ \\
\hline Human Capital & $\begin{array}{c}0.0330 \\
(0.0702)\end{array}$ & $\begin{array}{c}0.0243 \\
(0.0709)\end{array}$ & $\begin{array}{c}0.774 * * * \\
(0.268)\end{array}$ & $\begin{array}{c}0.808^{* *} \\
(0.280)\end{array}$ \\
\hline Inflation & $\begin{array}{c}0.738 \\
(1.104)\end{array}$ & $\begin{array}{c}0.556 \\
(1.124)\end{array}$ & $\begin{array}{c}0.923 \\
(1.185)\end{array}$ & $\begin{array}{c}0.386 \\
(1.568)\end{array}$ \\
\hline Government Size & $\begin{array}{c}-0.00974 \\
(0.455)\end{array}$ & $\begin{array}{l}-0.101 \\
(0.467) \\
\end{array}$ & $\begin{array}{c}-3.292 * * \\
(1.416)\end{array}$ & $\begin{array}{c}-3.212 * * \\
(1.452)\end{array}$ \\
\hline Trade Openness & $\begin{array}{l}-0.0397 \\
(0.0381)\end{array}$ & $\begin{array}{l}-0.0378 \\
(0.0382)\end{array}$ & $\begin{array}{l}-0.109 \\
(0.136)\end{array}$ & $\begin{array}{l}-0.142 \\
(0.151)\end{array}$ \\
\hline Deficit & $\begin{array}{l}0.0125 \\
(1.088)\end{array}$ & $\begin{array}{c}0.282 \\
(1.130)\end{array}$ & $\begin{array}{l}-3.129 \\
(1.824)\end{array}$ & $\begin{array}{c}-3.305^{*} \\
(1.890)\end{array}$ \\
\hline Debt & $\begin{array}{c}-0.420 * * \\
(0.178)\end{array}$ & $\begin{array}{c}-0.597^{* *} \\
(0.265)\end{array}$ & $\begin{array}{c}-1.077^{* *} \\
(0.421)\end{array}$ & $\begin{array}{c}-1.334 * \\
(0.643)\end{array}$ \\
\hline $\mathrm{CPI}$ & $\begin{array}{l}- \\
-\end{array}$ & $\begin{array}{l}-0.0226 \\
(0.0251)\end{array}$ & $\begin{array}{l}- \\
-\end{array}$ & $\begin{array}{l}-0.0331 \\
(0.0616)\end{array}$ \\
\hline Debt $^{*} \mathrm{CPI}$ & $\begin{array}{c}0.0485^{* *} \\
(0.0236)\end{array}$ & $\begin{array}{l}0.0730 \text { ** } \\
(0.0361)\end{array}$ & $\begin{array}{l}0.136^{* *} \\
(0.0475)\end{array}$ & $\begin{array}{l}0.170^{* *} \\
(0.0794)\end{array}$ \\
\hline Constant & $\begin{array}{c}1.920 * * * \\
(0.393)\end{array}$ & $\begin{array}{c}1.890^{* * *} \\
(0.395)\end{array}$ & $\begin{array}{c}1.665 \\
(1.205)\end{array}$ & $\begin{array}{c}1.683 \\
(1.230)\end{array}$ \\
\hline Observations & 64 & 64 & 64 & 64 \\
\hline$R$-squared & 0.953 & 0.954 & 0.916 & 0.918 \\
\hline
\end{tabular}

Table A7. Estimation results: ten-year average and 46 countries.

\begin{tabular}{|c|c|c|c|c|}
\hline \multirow{2}{*}{ Variables } & Model (1) & Model (2) & Model (3) & Model (4) \\
\hline & OLS & OLS & Fixed Effect & Fixed Effect \\
\hline Initial GDP & $\begin{array}{c}0.675^{* * *} \\
(0.0464)\end{array}$ & $\begin{array}{c}0.683 \text { *** } \\
(0.0503)\end{array}$ & $\begin{array}{c}0.204 \\
(0.150)\end{array}$ & $\begin{array}{c}0.222 \\
(0.150)\end{array}$ \\
\hline Human Capital & $\begin{array}{c}0.0310 \\
(0.0698)\end{array}$ & $\begin{array}{c}0.0261 \\
(0.0710)\end{array}$ & $\begin{array}{l}0.840^{* * *} \\
(0.307)\end{array}$ & $\begin{array}{l}0.775^{* *} \\
(0.310)\end{array}$ \\
\hline Inflation & $\begin{array}{c}1.169 \\
(1.084)\end{array}$ & $\begin{array}{c}1.052 \\
(1.120)\end{array}$ & $\begin{array}{c}1.505 \\
(1.338)\end{array}$ & $\begin{array}{c}2.874 \\
(1.773)\end{array}$ \\
\hline Government Size & $\begin{array}{l}-0.306 \\
(0.427)\end{array}$ & $\begin{array}{l}-0.297 \\
(0.430)\end{array}$ & $\begin{array}{c}-3.151^{* *} \\
(1.203)\end{array}$ & $\begin{array}{c}-3.345^{* *} \\
(1.206)\end{array}$ \\
\hline Trade Openness & $\begin{array}{c}0.0265 \\
(0.0330)\end{array}$ & $\begin{array}{c}0.0255 \\
(0.0332)\end{array}$ & $\begin{array}{c}0.200 \\
(0.118)\end{array}$ & $\begin{array}{l}0.237^{*} \\
(0.121)\end{array}$ \\
\hline Deficit & $\begin{array}{l}-0.982 \\
(0.683)\end{array}$ & $\begin{array}{l}-0.985 \\
(0.687)\end{array}$ & $\begin{array}{l}-0.648 \\
(1.258)\end{array}$ & $\begin{array}{l}-0.387 \\
(1.269)\end{array}$ \\
\hline Debt & $\begin{array}{c}-0.376^{* *} \\
(0.170)\end{array}$ & $\begin{array}{c}-0.455 \text { * } \\
(0.242)\end{array}$ & $\begin{array}{c}-1.093 \text { ** } \\
(0.496)\end{array}$ & $\begin{array}{l}-0.457 \\
(0.735)\end{array}$ \\
\hline CPI & - & $\begin{array}{l}-0.0102 \\
(0.0223)\end{array}$ & - & $\begin{array}{c}0.0810 \\
(0.0695)\end{array}$ \\
\hline Debt $^{*} \mathrm{CPI}$ & $\begin{array}{c}0.0555^{* *} \\
(0.0236)\end{array}$ & $\begin{array}{l}0.0671 * \\
(0.0346)\end{array}$ & $\begin{array}{l}0.129^{* *} \\
(0.0571)\end{array}$ & $\begin{array}{c}0.0450 \\
(0.0917)\end{array}$ \\
\hline Constant & $\begin{array}{c}2.309 * * * \\
(0.365)\end{array}$ & $\begin{array}{c}2.310 * * * \\
(0.367)\end{array}$ & $\begin{array}{c}5.007 * * * \\
(0.959)\end{array}$ & $\begin{array}{c}4.396^{* * *} \\
(1.086)\end{array}$ \\
\hline Observations & 79 & 79 & 79 & 79 \\
\hline$R$-squared & 0.943 & 0.943 & 0.832 & 0.841 \\
\hline
\end{tabular}


Table A8. Estimation results: ten-year average and 77 countries.

\begin{tabular}{|c|c|c|c|c|}
\hline \multirow{2}{*}{ Variables } & Model (1) & Model (2) & Model (3) & Model (4) \\
\hline & OLS & OLS & Fixed Effect & Fixed Effect \\
\hline Initial GDP & $\begin{array}{l}0.673^{* * *} \\
(0.0384)\end{array}$ & $\begin{array}{l}0.673^{* * *} \\
(0.0389)\end{array}$ & $\begin{array}{c}0.105 \\
(0.128) \\
\end{array}$ & $\begin{array}{c}0.119 \\
(0.140) \\
\end{array}$ \\
\hline Human Capital & $\begin{array}{l}0.242^{* * *} \\
(0.0603)\end{array}$ & $\begin{array}{l}0.243^{* * *} \\
(0.0614)\end{array}$ & $\begin{array}{c}0.857^{* * *} \\
(0.279)\end{array}$ & $\begin{array}{c}0.844^{* * *} \\
(0.287)\end{array}$ \\
\hline Inflation & $\begin{array}{c}-0.0299 \\
(0.710)\end{array}$ & $\begin{array}{c}-0.0350 \\
(0.715)\end{array}$ & $\begin{array}{l}-0.134 \\
(1.153)\end{array}$ & $\begin{array}{c}-0.0401 \\
(1.219)\end{array}$ \\
\hline Government Size & $\begin{array}{l}-0.236 \\
(0.403)\end{array}$ & $\begin{array}{l}-0.240 \\
(0.407)\end{array}$ & $\begin{array}{c}-4.134^{* * *} \\
(0.855)\end{array}$ & $\begin{array}{c}-4.011^{* * *} \\
(0.977)\end{array}$ \\
\hline Trade Openness & $\begin{array}{c}0.0337 \\
(0.0380)\end{array}$ & $\begin{array}{c}0.0342 \\
(0.0384)\end{array}$ & $\begin{array}{c}0.173 \\
(0.114)\end{array}$ & $\begin{array}{c}0.170 \\
(0.116)\end{array}$ \\
\hline Deficit & $\begin{array}{c}-1.143^{* *} \\
(0.502)\end{array}$ & $\begin{array}{c}-1.144^{* *} \\
(0.505)\end{array}$ & $\begin{array}{c}1.376 \\
(0.965)\end{array}$ & $\begin{array}{c}1.369 \\
(0.978) \\
\end{array}$ \\
\hline Debt & $\begin{array}{l}0.0238 \\
(0.143) \\
\end{array}$ & $\begin{array}{l}0.0128 \\
(0.176) \\
\end{array}$ & $\begin{array}{c}-0.715^{* *} \\
(0.269)\end{array}$ & $\begin{array}{c}-0.688^{* *} \\
(0.290)\end{array}$ \\
\hline CPI & $\begin{array}{l}- \\
-\end{array}$ & $\begin{array}{c}-0.00213 \\
(0.0198)\end{array}$ & $\begin{array}{l}- \\
-\end{array}$ & $\begin{array}{c}0.0133 \\
(0.0493)\end{array}$ \\
\hline Debt $^{*} \mathrm{CPI}$ & $\begin{array}{c}-2.01 \times 10^{-5} \\
(0.0231)\end{array}$ & $\begin{array}{l}0.00205 \\
(0.0302)\end{array}$ & $\begin{array}{l}0.0767 * \\
(0.0418)\end{array}$ & $\begin{array}{c}0.0700 \\
(0.0491)\end{array}$ \\
\hline Constant & $\begin{array}{c}1.669^{* * *} \\
(0.289)\end{array}$ & $\begin{array}{c}1.673^{* * *} \\
(0.293)\end{array}$ & $\begin{array}{c}6.066^{* * *} \\
(0.782)\end{array}$ & $\begin{array}{c}5.880^{* * *} \\
(1.050)\end{array}$ \\
\hline Observations & 121 & 121 & 121 & 121 \\
\hline$R$-squared & 0.946 & 0.946 & 0.776 & 0.776 \\
\hline
\end{tabular}

Estimation Results with the WGI index. 
Table A9. Estimation results: five-year period and 77 countries.

\begin{tabular}{|c|c|c|c|c|c|c|c|c|c|c|c|c|}
\hline & Model (1) & Model (1) & Model (2) & Model (2) & Model (3) & Model (3) & Model (4) & Model (4) & Model (5) & Model (5) & Model (6) & Model (6) \\
\hline Variables & $\begin{array}{l}\text { OLS } \\
\text { CPI }\end{array}$ & $\begin{array}{l}\text { OLS } \\
\text { WGI }\end{array}$ & $\begin{array}{l}\text { OLS } \\
\text { CPI }\end{array}$ & $\begin{array}{l}\text { OLS } \\
\text { WGI }\end{array}$ & $\begin{array}{c}\text { Fixed } \\
\text { Effect } \\
\text { CPI }\end{array}$ & $\begin{array}{l}\text { Fixed } \\
\text { Effect } \\
\text { WGI }\end{array}$ & $\begin{array}{c}\text { Fixed } \\
\text { Effect } \\
\text { CPI }\end{array}$ & $\begin{array}{l}\text { Fixed } \\
\text { Effect } \\
\text { WGI }\end{array}$ & $\underset{\text { CPI }}{\text { GMM }}$ & $\begin{array}{l}\text { GMM } \\
\text { WGI }\end{array}$ & $\underset{\text { CPI }}{\text { GMM }}$ & $\begin{array}{c}\text { GMM } \\
\text { WGI }\end{array}$ \\
\hline Initial GDP & $\begin{array}{c}-0.0207^{* * *} \\
(0.00388)\end{array}$ & $\begin{array}{c}-0.02144^{* * *} \\
(0.00399)\end{array}$ & $\begin{array}{c}-0.0201 * * * \\
(0.00392)\end{array}$ & $\begin{array}{c}-0.0206^{* * *} \\
(0.00402)\end{array}$ & $\begin{array}{c}-0.0997^{* * *} \\
(0.0117)\end{array}$ & $\begin{array}{c}-0.0967^{* * *} \\
(0.0136)\end{array}$ & $\begin{array}{c}-0.101 \text { *** } \\
(0.0116)\end{array}$ & $\begin{array}{c}-0.0960^{* * *} \\
(0.0137)\end{array}$ & $\begin{array}{c}-0.136^{* * *} \\
(0.0157)\end{array}$ & $\begin{array}{c}-0.130 * * * \\
(0.0157)\end{array}$ & $\begin{array}{c}-0.137^{* * *} \\
(0.0157)\end{array}$ & $\begin{array}{c}-0.130 \text { *** } \\
(0.0158)\end{array}$ \\
\hline $\begin{array}{l}\text { Human } \\
\text { Capital }\end{array}$ & $\begin{array}{c}0.0202 * * * \\
(0.00578)\end{array}$ & $\begin{array}{c}0.0260^{* * *} \\
(0.00594)\end{array}$ & $\begin{array}{l}0.0211^{* * *} \\
(0.00583)\end{array}$ & $\begin{array}{c}0.0271^{* * *} \\
(0.00597)\end{array}$ & $\begin{array}{c}0.0832 * * * \\
(0.0220)\end{array}$ & $\begin{array}{c}0.0706^{* * *} \\
(0.0265)\end{array}$ & $\begin{array}{c}0.0860^{* * *} \\
(0.0219)\end{array}$ & $\begin{array}{c}0.0733^{* * *} \\
(0.0269)\end{array}$ & $\begin{array}{c}0.0932 * * * \\
(0.0272)\end{array}$ & $\begin{array}{c}0.0864^{* * *} \\
(0.0276)\end{array}$ & $\begin{array}{c}0.0948^{* * *} \\
(0.0273)\end{array}$ & $\begin{array}{c}0.0841^{* * *} \\
(0.0280)\end{array}$ \\
\hline Inflation & $\begin{array}{l}0.00180 \\
(0.0413)\end{array}$ & $\begin{array}{l}0.00544 \\
(0.0456)\end{array}$ & $\begin{array}{c}-0.00408 \\
(0.0416)\end{array}$ & $\begin{array}{c}-0.00108 \\
(0.0457)\end{array}$ & $\begin{array}{c}-0.127 * * * \\
(0.0420)\end{array}$ & $\begin{array}{c}-0.127^{* *} \\
(0.0500)\end{array}$ & $\begin{array}{c}-0.110 * * \\
(0.0431)\end{array}$ & $\begin{array}{c}-0.121 * * \\
(0.0507)\end{array}$ & $\begin{array}{l}-0.0512 \\
(0.0538)\end{array}$ & $\begin{array}{c}-0.258^{* * *} \\
(0.0767)\end{array}$ & $\begin{array}{l}-0.0398 \\
(0.0555)\end{array}$ & $\begin{array}{c}-0.264^{* * *} \\
(0.0778)\end{array}$ \\
\hline $\begin{array}{l}\text { Government } \\
\text { Size }\end{array}$ & $\begin{array}{c}-0.00742 \\
(0.0361)\end{array}$ & $\begin{array}{l}0.00607 \\
(0.0382)\end{array}$ & $\begin{array}{l}-0.0131 \\
(0.0364)\end{array}$ & $\begin{array}{c}-0.00129 \\
(0.0385)\end{array}$ & $\begin{array}{c}-0.357^{* * *} \\
(0.0614)\end{array}$ & $\begin{array}{c}-0.286^{* * * *} \\
(0.0752)\end{array}$ & $\begin{array}{c}-0.344^{* * *} \\
(0.0616)\end{array}$ & $\begin{array}{c}-0.276^{* * *} \\
(0.0768)\end{array}$ & $\begin{array}{c}-0.267^{* * *} \\
(0.0766)\end{array}$ & $\begin{array}{c}0.0667^{* * *} \\
(0.0140)\end{array}$ & $\begin{array}{c}-0.264^{* * *} \\
(0.0768)\end{array}$ & $\begin{array}{c}0.0659 * * * \\
(0.0140)\end{array}$ \\
\hline $\begin{array}{c}\text { Trade } \\
\text { Openness }\end{array}$ & $\begin{array}{l}0.00629 * \\
(0.00355)\end{array}$ & $\begin{array}{c}-0.000542 \\
(0.00432)\end{array}$ & $\begin{array}{l}0.00690 * \\
(0.00359)\end{array}$ & $\begin{array}{l}0.000645 \\
(0.00439)\end{array}$ & $\begin{array}{l}0.0261^{* * *} \\
(0.00712)\end{array}$ & $\begin{array}{c}0.0484^{* * *} \\
(0.0132)\end{array}$ & $\begin{array}{l}0.0250^{* * *} \\
(0.00712)\end{array}$ & $\begin{array}{c}0.0490^{* * *} \\
(0.0132)\end{array}$ & $\begin{array}{c}0.0644^{* * *} \\
(0.0139)\end{array}$ & $\begin{array}{c}0.0709 \\
(0.0659)\end{array}$ & $\begin{array}{c}0.0643^{* * *} \\
(0.0139)\end{array}$ & $\begin{array}{c}0.0621 \\
(0.0672)\end{array}$ \\
\hline Deficit & $\begin{array}{l}-0.0537 \\
(0.0361)\end{array}$ & $\begin{array}{c}-0.0839 * * \\
(0.0362)\end{array}$ & $\begin{array}{l}-0.0546 \\
(0.0360)\end{array}$ & $\begin{array}{c}-0.0892 * * \\
(0.0363)\end{array}$ & $\begin{array}{c}0.0264 \\
(0.0485)\end{array}$ & $\begin{array}{l}-0.0181 \\
(0.0599)\end{array}$ & $\begin{array}{c}0.0377 \\
(0.0488)\end{array}$ & $\begin{array}{c}-0.00893 \\
(0.0614)\end{array}$ & $\begin{array}{c}0.0567 \\
(0.0653)\end{array}$ & $\begin{array}{l}-0.0103 \\
(0.0118)\end{array}$ & $\begin{array}{c}0.0645 \\
(0.0658)\end{array}$ & $\begin{array}{c}-0.00961 \\
(0.0119)\end{array}$ \\
\hline Debt & $\begin{array}{c}-0.00314 \\
(0.0124)\end{array}$ & $\begin{array}{l}0.000193 \\
(0.00670)\end{array}$ & $\begin{array}{l}-0.0135 \\
(0.0155)\end{array}$ & $\begin{array}{l}-0.00130 \\
(0.00677)\end{array}$ & $\begin{array}{c}-0.0300 * \\
(0.0179)\end{array}$ & $\begin{array}{c}-0.000151 \\
(0.0114)\end{array}$ & $\begin{array}{l}-0.0149 \\
(0.0201)\end{array}$ & $\begin{array}{c}-0.000905 \\
(0.0115)\end{array}$ & $\begin{array}{c}-0.0542 * * \\
(0.0229)\end{array}$ & $\begin{array}{l}-0.0703 \\
(0.0528)\end{array}$ & $\begin{array}{c}-0.0443 * \\
(0.0251)\end{array}$ & $\begin{array}{l}-0.0740 \\
(0.0534)\end{array}$ \\
\hline CPI or WGI & - & - & $\begin{array}{l}-0.00209 \\
(0.00189)\end{array}$ & $\begin{array}{l}-0.00572 \\
(0.00401)\end{array}$ & - & - & $\begin{array}{c}0.00712 \\
(0.00439)\end{array}$ & $\begin{array}{l}0.00753 \\
(0.0109)\end{array}$ & - & - & $\begin{array}{c}0.00449 \\
(0.00505)\end{array}$ & $\begin{array}{c}-0.00575 \\
(0.0113)\end{array}$ \\
\hline $\begin{array}{l}\text { Debt*CPI } \\
\text { or WGI }\end{array}$ & $\begin{array}{l}0.000558 \\
(0.00206)\end{array}$ & $\begin{array}{l}-0.00434 \\
(0.00461)\end{array}$ & $\begin{array}{c}0.00259 \\
(0.00276)\end{array}$ & $\begin{array}{l}0.000911 \\
(0.00589)\end{array}$ & $\begin{array}{c}0.00678^{* *} \\
(0.00317)\end{array}$ & $\begin{array}{c}0.0125 \\
(0.00927)\end{array}$ & $\begin{array}{c}0.00322 \\
(0.00384)\end{array}$ & $\begin{array}{l}0.00892 \\
(0.0106)\end{array}$ & $\begin{array}{l}0.0101 \text { ** } \\
(0.00474)\end{array}$ & $\begin{array}{c}0.0150 \\
(0.00964)\end{array}$ & $\begin{array}{c}0.00783 \\
(0.00541)\end{array}$ & $\begin{array}{c}0.0176 \\
(0.0110)\end{array}$ \\
\hline Constant & $\begin{array}{l}0.167 * * * \\
(0.0297)\end{array}$ & $\begin{array}{l}0.160 * * * \\
(0.0308)\end{array}$ & $\begin{array}{l}0.171^{* * *} \\
(0.0299)\end{array}$ & $\begin{array}{l}0.153^{* * *} \\
(0.0311)\end{array}$ & $\begin{array}{l}0.796^{* * *} \\
(0.0823)\end{array}$ & $\begin{array}{c}0.772 \text { *** } \\
(0.106)\end{array}$ & $\begin{array}{l}0.759^{* * *} \\
(0.0850)\end{array}$ & $\begin{array}{c}0.753^{* * *} \\
(0.109)\end{array}$ & $\begin{array}{c}1.067^{* * *} \\
(0.118)\end{array}$ & $\begin{array}{c}1.028^{* * *} \\
(0.117)\end{array}$ & $\begin{array}{c}1.044^{* * *} \\
(0.122)\end{array}$ & $\begin{array}{c}1.036^{* * *} \\
(0.121)\end{array}$ \\
\hline Observations & 258 & 224 & 258 & 224 & 258 & 224 & 258 & 224 & 144 & 147 & 144 & 147 \\
\hline$R$-squared & 0.133 & 0.208 & 0.137 & 0.216 & 0.468 & 0.413 & 0.476 & 0.415 & & & & \\
\hline
\end{tabular}

Standard errors in parentheses; ${ }^{* * *} p<0.01{ }^{* *} p<0.05,{ }^{*} p<0.1$ 
Table A10. Estimation results: five-year period and 38 countries.

\begin{tabular}{|c|c|c|c|c|c|c|c|c|c|c|c|c|}
\hline & Model (1) & Model (1) & Model (2) & Model (2) & Model (3) & Model (3) & Model (4) & Model (4) & Model (5) & Model (5) & Model (6) & Model (6) \\
\hline Variables & $\begin{array}{l}\text { OLS } \\
\text { CPI }\end{array}$ & $\begin{array}{l}\text { OLS } \\
\text { WGI }\end{array}$ & $\begin{array}{l}\text { OLS } \\
\text { CPI }\end{array}$ & $\begin{array}{l}\text { OLS } \\
\text { WGI }\end{array}$ & $\begin{array}{c}\text { Fixed } \\
\text { Effect } \\
\text { CPI }\end{array}$ & $\begin{array}{l}\text { Fixed } \\
\text { Effect } \\
\text { WGI }\end{array}$ & $\begin{array}{c}\text { Fixed } \\
\text { Effect } \\
\text { CPI }\end{array}$ & $\begin{array}{l}\text { Fixed } \\
\text { Effect } \\
\text { WGI }\end{array}$ & $\underset{\text { CPI }}{\text { GMM }}$ & $\begin{array}{c}\text { GMM } \\
\text { WGI }\end{array}$ & $\underset{\text { CPI }}{\text { GMM }}$ & $\begin{array}{c}\text { GMM } \\
\text { WGI }\end{array}$ \\
\hline Initial GDP & $\begin{array}{c}-0.0214 * * * \\
(0.00478)\end{array}$ & $\begin{array}{c}-0.0281^{* * *} \\
(0.00463)\end{array}$ & $\begin{array}{c}-0.0188^{* * * *} \\
(0.00523)\end{array}$ & $\begin{array}{c}-0.0237 * * * \\
(0.00514)\end{array}$ & $\begin{array}{c}-0.0740^{* * *} \\
(0.0146)\end{array}$ & $\begin{array}{c}-0.0755^{* * * *} \\
(0.0156)\end{array}$ & $\begin{array}{c}-0.0734^{* * *} \\
(0.0148)\end{array}$ & $\begin{array}{c}-0.0755^{* * * *} \\
(0.0157)\end{array}$ & $\begin{array}{c}-0.0993 * * * \\
(0.0220)\end{array}$ & $\begin{array}{c}-0.0931 \text { *** } \\
(0.0210)\end{array}$ & $\begin{array}{c}-0.0921^{* * * *} \\
(0.0222)\end{array}$ & $\begin{array}{c}-0.0872^{* * *} \\
(0.0211)\end{array}$ \\
\hline $\begin{array}{l}\text { Human } \\
\text { Capital }\end{array}$ & $\begin{array}{c}0.0107 \\
(0.00649)\end{array}$ & $\begin{array}{l}0.0128^{* *} \\
(0.00614)\end{array}$ & $\begin{array}{c}0.00995 \\
(0.00650)\end{array}$ & $\begin{array}{c}0.0117^{*} \\
(0.00609)\end{array}$ & $\begin{array}{c}0.0994^{* * *} \\
(0.0271)\end{array}$ & $\begin{array}{c}0.123^{* * *} \\
(0.0295)\end{array}$ & $\begin{array}{c}0.0990^{* * *} \\
(0.0272)\end{array}$ & $\begin{array}{c}0.122 * * * \\
(0.0306)\end{array}$ & $\begin{array}{c}0.135^{* * *} \\
(0.0331)\end{array}$ & $\begin{array}{c}0.145^{* * *} \\
(0.0318)\end{array}$ & $\begin{array}{c}0.132^{* * *} \\
(0.0329)\end{array}$ & $\begin{array}{c}0.137^{* * *} \\
(0.0329)\end{array}$ \\
\hline Inflation & $\begin{array}{l}-0.0438 \\
(0.0413)\end{array}$ & $\begin{array}{c}0.0478 \\
(0.0399)\end{array}$ & $\begin{array}{l}-0.0470 \\
(0.0413)\end{array}$ & $\begin{array}{c}0.0306 \\
(0.0405)\end{array}$ & $\begin{array}{c}-0.115^{* *} \\
(0.0448)\end{array}$ & $\begin{array}{c}-0.230 \text { ** } \\
(0.0983)\end{array}$ & $\begin{array}{c}-0.117^{* *} \\
(0.0455)\end{array}$ & $\begin{array}{c}-0.232 \text { ** } \\
(0.101)\end{array}$ & $\begin{array}{l}-0.0811 \\
(0.0566)\end{array}$ & $\begin{array}{c}-0.205^{* *} \\
(0.103)\end{array}$ & $\begin{array}{l}-0.101 \text { * } \\
(0.0575)\end{array}$ & $\begin{array}{c}-0.232 \text { ** } \\
(0.105)\end{array}$ \\
\hline $\begin{array}{l}\text { Government } \\
\text { Size }\end{array}$ & $\begin{array}{c}-0.00341 \\
(0.0417)\end{array}$ & $\begin{array}{l}-0.00290 \\
(0.00375)\end{array}$ & $\begin{array}{l}-0.0142 \\
(0.0425)\end{array}$ & $\begin{array}{l}-0.00198 \\
(0.00373)\end{array}$ & $\begin{array}{c}-0.393^{* * *} \\
(0.0819)\end{array}$ & $\begin{array}{c}0.0108 \\
(0.0118)\end{array}$ & $\begin{array}{c}-0.393^{* * *} \\
(0.0823)\end{array}$ & $\begin{array}{c}0.0107 \\
(0.0120)\end{array}$ & $\begin{array}{c}-0.248^{* *} \\
(0.107)\end{array}$ & $\begin{array}{c}0.0106 \\
(0.0145)\end{array}$ & $\begin{array}{c}-0.249 \text { ** } \\
(0.106)\end{array}$ & $\begin{array}{l}0.00516 \\
(0.0147)\end{array}$ \\
\hline $\begin{array}{c}\text { Trade } \\
\text { Openness }\end{array}$ & $\begin{array}{l}-0.00270 \\
(0.00401)\end{array}$ & $\begin{array}{l}-0.0630 \\
(0.0613)\end{array}$ & $\begin{array}{l}-0.00215 \\
(0.00403)\end{array}$ & $\begin{array}{l}-0.0611 \\
(0.0605)\end{array}$ & $\begin{array}{l}0.00209 \\
(0.0116) \\
\end{array}$ & $\begin{array}{l}-0.0419 \\
(0.0796)\end{array}$ & $\begin{array}{l}0.00219 \\
(0.0116) \\
\end{array}$ & $\begin{array}{l}-0.0425 \\
(0.0805)\end{array}$ & $\begin{array}{c}0.0120 \\
(0.0151) \\
\end{array}$ & $\begin{array}{l}-0.0602 \\
(0.0888)\end{array}$ & $\begin{array}{l}0.00814 \\
(0.0150) \\
\end{array}$ & $\begin{array}{l}-0.0706 \\
(0.0891)\end{array}$ \\
\hline Deficit & $\begin{array}{c}0.0841 \\
(0.0612)\end{array}$ & $\begin{array}{l}-0.0113 \\
(0.00806)\end{array}$ & $\begin{array}{c}0.0892 \\
(0.0612) \\
\end{array}$ & $\begin{array}{c}-0.0195^{* *} \\
(0.00907)\end{array}$ & $\begin{array}{l}0.139 * * \\
(0.0643)\end{array}$ & $\begin{array}{c}-0.0367^{* *} \\
(0.0174)\end{array}$ & $\begin{array}{l}0.137^{* *} \\
(0.0649)\end{array}$ & $\begin{array}{c}-0.0369^{* *} \\
(0.0176)\end{array}$ & $\begin{array}{l}-0.0271 \\
(0.0924) \\
\end{array}$ & $\begin{array}{c}-0.04155^{* *} \\
(0.0198)\end{array}$ & $\begin{array}{l}-0.0354 \\
(0.0926) \\
\end{array}$ & $\begin{array}{c}-0.0446 \text { ** } \\
(0.0201)\end{array}$ \\
\hline Debt & $\begin{array}{l}-0.0226 \\
(0.0148) \\
\end{array}$ & $\begin{array}{l}-0.0393 \\
(0.0417) \\
\end{array}$ & $\begin{array}{c}-0.0415 * \\
(0.0213)\end{array}$ & $\begin{array}{l}-0.0462 \\
(0.0413)\end{array}$ & $\begin{array}{c}-0.0449 * \\
(0.0269)\end{array}$ & $\begin{array}{c}-0.0970 * \\
(0.0495)\end{array}$ & $\begin{array}{l}-0.0501 \\
(0.0326) \\
\end{array}$ & $\begin{array}{c}-0.0975 * \\
(0.0502)\end{array}$ & $\begin{array}{c}-0.0786^{*} \\
(0.0403)\end{array}$ & $\begin{array}{l}-0.0750 \\
(0.0543) \\
\end{array}$ & $\begin{array}{c}-0.105^{* *} \\
(0.0432)\end{array}$ & $\begin{array}{l}-0.0869 \\
(0.0547) \\
\end{array}$ \\
\hline CPI or WGI & - & - & $\begin{array}{l}-0.00282 \\
(0.00228)\end{array}$ & $\begin{array}{c}-0.00846^{*} \\
(0.00449)\end{array}$ & $\begin{array}{l}- \\
-\end{array}$ & - & $\begin{array}{l}-0.00150 \\
(0.00531)\end{array}$ & $\begin{array}{c}-0.00138 \\
(0.0138)\end{array}$ & - & $\begin{array}{l}- \\
-\end{array}$ & $\begin{array}{l}-0.00805 \\
(0.00621)\end{array}$ & $\begin{array}{l}-0.0160 \\
(0.0154)\end{array}$ \\
\hline $\begin{array}{c}\text { Debt*CPI }^{*} \text { or WGI }\end{array}$ & $\begin{array}{c}0.00168 \\
(0.00212)\end{array}$ & $\begin{array}{c}0.00311 \\
(0.00469)\end{array}$ & $\begin{array}{c}0.00464 \\
(0.00319)\end{array}$ & $\begin{array}{c}0.0112 * \\
(0.00631)\end{array}$ & $\begin{array}{l}0.00627^{*} \\
(0.00341)\end{array}$ & $\begin{array}{l}0.0261 \text { *** } \\
(0.00856)\end{array}$ & $\begin{array}{c}0.00719 \\
(0.00473)\end{array}$ & $\begin{array}{c}0.0268 * * \\
(0.0110)\end{array}$ & $\begin{array}{l}0.00957^{*} \\
(0.00573)\end{array}$ & $\begin{array}{l}0.0305 * * * \\
(0.00927)\end{array}$ & $\begin{array}{l}0.0148 \text { *** } \\
(0.00658)\end{array}$ & $\begin{array}{c}0.0391 \text { *** } \\
(0.0122)\end{array}$ \\
\hline Constant & $\begin{array}{l}0.214^{* * *} \\
(0.0375)\end{array}$ & $\begin{array}{l}0.267^{* * *} \\
(0.0372)\end{array}$ & $\begin{array}{l}0.209 * * * \\
(0.0377)\end{array}$ & $\begin{array}{l}0.237^{* * *} \\
(0.0401)\end{array}$ & $\begin{array}{c}0.534^{* * *} \\
(0.101)\end{array}$ & $\begin{array}{c}0.458^{* * *} \\
(0.115)\end{array}$ & $\begin{array}{c}0.539 * * * \\
(0.103)\end{array}$ & $\begin{array}{c}0.461^{* * *} \\
(0.120)\end{array}$ & $\begin{array}{c}0.660 * * * \\
(0.173)\end{array}$ & $\begin{array}{c}0.562 * * * \\
(0.164)\end{array}$ & $\begin{array}{c}0.647^{* * *} \\
(0.171)\end{array}$ & $\begin{array}{c}0.549 * * * \\
(0.163)\end{array}$ \\
\hline Observations & 137 & 111 & 137 & 111 & 137 & 111 & 137 & 111 & 73 & 73 & 73 & 73 \\
\hline$R$-squared & 0.281 & 0.483 & 0.289 & 0.501 & 0.384 & 0.398 & 0.384 & 0.398 & & & & \\
\hline $\begin{array}{l}\text { Number of } \\
\text { code }\end{array}$ & & & & & & 38 & & 38 & & 38 & & 38 \\
\hline
\end{tabular}


Table A11. Estimation results: five-year average and 38 countries.

\begin{tabular}{|c|c|c|c|c|c|c|c|c|c|c|c|c|}
\hline & Model (1) & Model (1) & Model (2) & Model (2) & Model (3) & Model (3) & Model (4) & Model (4) & Model (5) & Model (5) & Model (6) & Model (6) \\
\hline Variables & $\underset{\text { CPI }}{\text { OLS }}$ & $\begin{array}{l}\text { OLS } \\
\text { WGI }\end{array}$ & $\begin{array}{l}\text { OLS } \\
\text { CPI }\end{array}$ & $\begin{array}{l}\text { OLS } \\
\text { WGI }\end{array}$ & $\begin{array}{c}\text { Fixed } \\
\text { Effect } \\
\text { CPI }\end{array}$ & $\begin{array}{l}\text { Fixed } \\
\text { Effect } \\
\text { WGI }\end{array}$ & $\begin{array}{c}\text { Fixed } \\
\text { Effect } \\
\text { CPI }\end{array}$ & $\begin{array}{l}\text { Fixed } \\
\text { Effect } \\
\text { WGI }\end{array}$ & $\underset{\text { CPI }}{\text { GMM }}$ & $\begin{array}{c}\text { GMM } \\
\text { WGI }\end{array}$ & $\underset{\text { CPI }}{\text { GMM }}$ & $\begin{array}{c}\text { GMM } \\
\text { WGI }\end{array}$ \\
\hline Initial GDP & $\begin{array}{c}-0.0197^{* * *} \\
(0.00475)\end{array}$ & $\begin{array}{c}-0.0274^{* * *} \\
(0.00453)\end{array}$ & $\begin{array}{c}-0.0155 * * * \\
(0.00534)\end{array}$ & $\begin{array}{c}-0.02144^{* * *} \\
(0.00519)\end{array}$ & $\begin{array}{c}-0.0759 * * * \\
(0.0140)\end{array}$ & $\begin{array}{c}-0.0714^{* * *} \\
(0.0145)\end{array}$ & $\begin{array}{c}-0.0732^{* * *} \\
(0.0141)\end{array}$ & $\begin{array}{c}-0.0708^{* * *} \\
(0.0145)\end{array}$ & $\begin{array}{c}-0.0936^{* * *} \\
(0.0203)\end{array}$ & $\begin{array}{c}-0.0865^{* * *} \\
(0.0191)\end{array}$ & $\begin{array}{c}-0.0800^{* * *} \\
(0.0200)\end{array}$ & $\begin{array}{c}-0.0749^{* * *} \\
(0.0191)\end{array}$ \\
\hline $\begin{array}{l}\text { Human } \\
\text { Capital }\end{array}$ & $\begin{array}{c}0.00824 \\
(0.00661) \\
\end{array}$ & $\begin{array}{c}0.0112 * \\
(0.00626)\end{array}$ & $\begin{array}{c}0.00652 \\
(0.00664)\end{array}$ & $\begin{array}{c}0.00917 \\
(0.00620)\end{array}$ & $\begin{array}{l}0.128^{* * *} \\
(0.0285)\end{array}$ & $\begin{array}{l}0.138^{* * *} \\
(0.0303)\end{array}$ & $\begin{array}{l}0.128 * * * \\
(0.0284)\end{array}$ & $\begin{array}{l}0.131 * * * \\
(0.0313)\end{array}$ & $\begin{array}{l}0.152 * * * \\
(0.0328)\end{array}$ & $\begin{array}{c}0.173^{* * *} \\
(0.0317)\end{array}$ & $\begin{array}{c}0.144^{* * *} \\
(0.0317)\end{array}$ & $\begin{array}{l}0.154^{* * *} \\
(0.0326)\end{array}$ \\
\hline Inflation & $\begin{array}{l}-0.0511 \\
(0.0607) \\
\end{array}$ & $\begin{array}{c}0.0541 \\
(0.0401) \\
\end{array}$ & $\begin{array}{l}-0.0640 \\
(0.0607)\end{array}$ & $\begin{array}{c}0.0331 \\
(0.0404) \\
\end{array}$ & $\begin{array}{l}-0.105 \\
(0.0723)\end{array}$ & $\begin{array}{l}-0.127 \\
(0.118)\end{array}$ & $\begin{array}{l}-0.109 \\
(0.0722) \\
\end{array}$ & $\begin{array}{l}-0.146 \\
(0.120)\end{array}$ & $\begin{array}{l}-0.0396 \\
(0.0889)\end{array}$ & $\begin{array}{l}-0.183 \\
(0.125)\end{array}$ & $\begin{array}{l}-0.0655 \\
(0.0863)\end{array}$ & $\begin{array}{c}-0.229 * \\
(0.124)\end{array}$ \\
\hline $\begin{array}{l}\text { Government } \\
\text { Size }\end{array}$ & $\begin{array}{c}0.0117 \\
(0.0421) \\
\end{array}$ & $\begin{array}{l}-0.00356 \\
(0.00342)\end{array}$ & $\begin{array}{c}-0.00328 \\
(0.0428)\end{array}$ & $\begin{array}{l}-0.00251 \\
(0.00339)\end{array}$ & $\begin{array}{c}-0.454^{* * *} \\
(0.0947)\end{array}$ & $\begin{array}{c}0.0107 \\
(0.0111)\end{array}$ & $\begin{array}{c}-0.455^{* * *} \\
(0.0943)\end{array}$ & $\begin{array}{l}0.00947 \\
(0.0112) \\
\end{array}$ & $\begin{array}{c}-0.253 \text { * } \\
(0.132)\end{array}$ & $\begin{array}{l}0.00441 \\
(0.0129) \\
\end{array}$ & $\begin{array}{c}-0.255^{* *} \\
(0.128)\end{array}$ & $\begin{array}{c}-0.00344 \\
(0.0131)\end{array}$ \\
\hline $\begin{array}{c}\text { Trade } \\
\text { Openness }\end{array}$ & $\begin{array}{l}-0.00401 \\
(0.00374)\end{array}$ & $\begin{array}{l}-0.0414 \\
(0.0829)\end{array}$ & $\begin{array}{l}-0.00335 \\
(0.00374)\end{array}$ & $\begin{array}{l}-0.0132 \\
(0.0822)\end{array}$ & $\begin{array}{c}-0.00369 \\
(0.0109)\end{array}$ & $\begin{array}{l}-0.190 \\
(0.120)\end{array}$ & $\begin{array}{c}-0.00375 \\
(0.0109)\end{array}$ & $\begin{array}{c}-0.210 * \\
(0.122)\end{array}$ & $\begin{array}{l}0.00611 \\
(0.0136) \\
\end{array}$ & $\begin{array}{l}-0.172 \\
(0.131)\end{array}$ & $\begin{array}{c}0.000569 \\
(0.0133)\end{array}$ & $\begin{array}{c}-0.222 * \\
(0.131)\end{array}$ \\
\hline Deficit & $\begin{array}{c}0.0533 \\
(0.0882)\end{array}$ & $\begin{array}{c}-0.0176^{* *} \\
(0.00829)\end{array}$ & $\begin{array}{c}0.0746 \\
(0.0885)\end{array}$ & $\begin{array}{c}-0.0292^{* * *} \\
(0.00959)\end{array}$ & $\begin{array}{l}0.0343 \\
(0.120)\end{array}$ & $\begin{array}{c}-0.0685^{* * *} \\
(0.0156)\end{array}$ & $\begin{array}{c}-0.00495 \\
(0.123)\end{array}$ & $\begin{array}{c}-0.0720^{* * *} \\
(0.0160)\end{array}$ & $\begin{array}{l}-0.0588 \\
(0.138)\end{array}$ & $\begin{array}{c}-0.0810^{* * *} \\
(0.0170)\end{array}$ & $\begin{array}{l}-0.114 \\
(0.139)\end{array}$ & $\begin{array}{c}-0.0867^{* * *} \\
(0.0174)\end{array}$ \\
\hline Debt & $\begin{array}{c}-0.0291 * \\
(0.0158)\end{array}$ & $\begin{array}{l}-0.0281 \\
(0.0584)\end{array}$ & $\begin{array}{c}-0.0567^{* *} \\
(0.0226)\end{array}$ & $\begin{array}{l}-0.0484 \\
(0.0579)\end{array}$ & $\begin{array}{c}-0.0837^{* * * *} \\
(0.0277)\end{array}$ & $\begin{array}{l}-0.0181 \\
(0.0782) \\
\end{array}$ & $\begin{array}{c}-0.112^{* * *} \\
(0.0350)\end{array}$ & $\begin{array}{l}-0.0195 \\
(0.0783)\end{array}$ & $\begin{array}{c}-0.166^{* * *} \\
(0.0380)\end{array}$ & $\begin{array}{l}-0.0284 \\
(0.0841) \\
\end{array}$ & $\begin{array}{c}-0.210^{* * *} \\
(0.0411)\end{array}$ & $\begin{array}{l}-0.0480 \\
(0.0825)\end{array}$ \\
\hline CPI or WGI & - & - & $\begin{array}{c}-0.00387^{*} \\
(0.00228)\end{array}$ & $\begin{array}{c}-0.0100 * * \\
(0.00442)\end{array}$ & - & - & $\begin{array}{l}-0.00713 \\
(0.00545)\end{array}$ & $\begin{array}{l}-0.0129 \\
(0.0134)\end{array}$ & - & - & $\begin{array}{c}-0.0123 * * \\
(0.00574)\end{array}$ & $\begin{array}{c}-0.0245 * \\
(0.0144)\end{array}$ \\
\hline $\begin{array}{c}\text { Debt }^{*} \text { CPI } \\
\text { or WGI }\end{array}$ & $\begin{array}{c}0.00239 \\
(0.00217)\end{array}$ & $\begin{array}{c}0.00542 \\
(0.00449)\end{array}$ & $\begin{array}{c}0.00650 * * \\
(0.00324)\end{array}$ & $\begin{array}{l}0.0149 \text { ** } \\
(0.00606)\end{array}$ & $\begin{array}{c}0.0102 * * * \\
(0.00350)\end{array}$ & $\begin{array}{c}0.0342 * * * \\
(0.00790)\end{array}$ & $\begin{array}{c}0.0149 * * * \\
(0.00502)\end{array}$ & $\begin{array}{c}0.0404 * * * \\
(0.0102)\end{array}$ & $\begin{array}{c}0.0185^{* * *} \\
(0.00545)\end{array}$ & $\begin{array}{c}0.0415^{* * *} \\
(0.00819)\end{array}$ & $\begin{array}{c}0.0268 * * * \\
(0.00616)\end{array}$ & $\begin{array}{c}0.0538^{* * *} \\
(0.0107)\end{array}$ \\
\hline Constant & $\begin{array}{l}0.206^{* * *} \\
(0.0372)\end{array}$ & $\begin{array}{l}0.266^{* * *} \\
(0.0361)\end{array}$ & $\begin{array}{l}0.195^{* * *} \\
(0.0374)\end{array}$ & $\begin{array}{l}0.224^{* * *} \\
(0.0398)\end{array}$ & $\begin{array}{c}0.492 * * * \\
(0.0948)\end{array}$ & $\begin{array}{c}0.367^{* * *} \\
(0.102)\end{array}$ & $\begin{array}{l}0.509^{* * *} \\
(0.0953)\end{array}$ & $\begin{array}{c}0.394^{* * *} \\
(0.106)\end{array}$ & $\begin{array}{c}0.575^{* * *} \\
(0.153)\end{array}$ & $\begin{array}{c}0.433^{* * *} \\
(0.142)\end{array}$ & $\begin{array}{c}0.543^{* * *} \\
(0.148)\end{array}$ & $\begin{array}{c}0.407^{* * *} \\
(0.138)\end{array}$ \\
\hline Observations & 137 & 111 & 137 & 111 & 137 & 111 & 137 & 111 & 73 & 73 & 73 & 73 \\
\hline$R$-squared & 0.287 & 0.495 & 0.303 & 0.520 & 0.398 & 0.468 & 0.410 & 0.475 & & & & \\
\hline
\end{tabular}

Standard errors in parentheses; ${ }^{* * *} p<0.01{ }^{* *} p<0.05,{ }^{*} p<0.1$ 
Table A12. Estimation results: five-year average and 46 countries.

\begin{tabular}{|c|c|c|c|c|c|c|c|c|c|c|c|c|}
\hline & Model (1) & Model (1) & Model (2) & Model (2) & Model (3) & Model (3) & Model (4) & Model (4) & Model (5) & Model (5) & Model (6) & Model (6) \\
\hline Variables & $\underset{\text { CPI }}{\text { OLS }}$ & $\begin{array}{l}\text { OLS } \\
\text { WGI }\end{array}$ & $\begin{array}{l}\text { OLS } \\
\text { CPI }\end{array}$ & $\begin{array}{l}\text { OLS } \\
\text { WGI }\end{array}$ & $\begin{array}{c}\text { Fixed } \\
\text { Effect } \\
\text { CPI }\end{array}$ & $\begin{array}{l}\text { Fixed } \\
\text { Effect } \\
\text { WGI }\end{array}$ & $\begin{array}{c}\text { Fixed } \\
\text { Effect } \\
\text { CPI }\end{array}$ & $\begin{array}{l}\text { Fixed } \\
\text { Effect } \\
\text { WGI }\end{array}$ & $\underset{\text { CPI }}{\text { GMM }}$ & $\begin{array}{c}\text { GMM } \\
\text { WGI }\end{array}$ & $\underset{\text { CPI }}{\text { GMM }}$ & $\begin{array}{c}\text { GMM } \\
\text { WGI }\end{array}$ \\
\hline Initial GDP & $\begin{array}{c}-0.0253 \text { *** } \\
(0.00464)\end{array}$ & $\begin{array}{c}-0.0301 * * * \\
(0.00435)\end{array}$ & $\begin{array}{c}-0.0235 \text { *** } \\
(0.00513)\end{array}$ & $\begin{array}{c}-0.0258 \text { *** } \\
(0.00490)\end{array}$ & $\begin{array}{c}-0.0906^{* * *} \\
(0.0121)\end{array}$ & $\begin{array}{c}-0.0723^{* * *} \\
(0.0141)\end{array}$ & $\begin{array}{c}-0.0894^{* * *} \\
(0.0123)\end{array}$ & $\begin{array}{c}-0.0710^{* * *} \\
(0.0139)\end{array}$ & $\begin{array}{c}-0.119^{* * *} \\
(0.0202)\end{array}$ & $\begin{array}{c}-0.111^{* * *} \\
(0.0201)\end{array}$ & $\begin{array}{c}-0.111^{* * *} \\
(0.0205)\end{array}$ & $\begin{array}{c}-0.0997^{* * *} \\
(0.0202)\end{array}$ \\
\hline $\begin{array}{l}\text { Human } \\
\text { Capital }\end{array}$ & $\begin{array}{c}0.00681 \\
(0.00671)\end{array}$ & $\begin{array}{c}0.0115^{*} \\
(0.00616)\end{array}$ & $\begin{array}{c}0.00593 \\
(0.00680)\end{array}$ & $\begin{array}{c}0.0100 \\
(0.00615)\end{array}$ & $\begin{array}{c}0.0984^{* * *} \\
(0.0237)\end{array}$ & $\begin{array}{l}0.108^{* * *} \\
(0.0253)\end{array}$ & $\begin{array}{c}0.0966^{* * * *} \\
(0.0239)\end{array}$ & $\begin{array}{c}0.0949^{* * *} \\
(0.0261)\end{array}$ & $\begin{array}{l}0.140 * * * \\
(0.0296)\end{array}$ & $\begin{array}{c}0.145^{* * *} \\
(0.0300)\end{array}$ & $\begin{array}{c}0.130^{* * *} \\
(0.0298)\end{array}$ & $\begin{array}{l}0.121 * * * \\
(0.0318)\end{array}$ \\
\hline Inflation & $\begin{array}{l}-0.0166 \\
(0.0649) \\
\end{array}$ & $\begin{array}{c}0.0298 \\
(0.0396) \\
\end{array}$ & $\begin{array}{l}-0.0263 \\
(0.0660) \\
\end{array}$ & $\begin{array}{c}0.0254 \\
(0.0393) \\
\end{array}$ & $\begin{array}{l}-0.119 \\
(0.0722) \\
\end{array}$ & $\begin{array}{l}-0.145 \\
(0.113)\end{array}$ & $\begin{array}{l}-0.125^{*} \\
(0.0729)\end{array}$ & $\begin{array}{l}-0.175 \\
(0.112)\end{array}$ & $\begin{array}{l}-0.0311 \\
(0.0974)\end{array}$ & $\begin{array}{c}-0.279 \text { ** } \\
(0.129)\end{array}$ & $\begin{array}{l}-0.0493 \\
(0.0964)\end{array}$ & $\begin{array}{c}-0.305^{* *} \\
(0.126)\end{array}$ \\
\hline $\begin{array}{l}\text { Government } \\
\text { Size }\end{array}$ & $\begin{array}{l}-0.0233 \\
(0.0411) \\
\end{array}$ & $\begin{array}{l}0.000303 \\
(0.00314)\end{array}$ & $\begin{array}{l}-0.0230 \\
(0.0411) \\
\end{array}$ & $\begin{array}{l}0.000380 \\
(0.00311)\end{array}$ & $\begin{array}{c}-0.433^{* * *} \\
(0.0783)\end{array}$ & $\begin{array}{l}0.0232 * \\
(0.0117)\end{array}$ & $\begin{array}{c}-0.431^{* * *} \\
(0.0786)\end{array}$ & $\begin{array}{l}0.0203^{*} \\
(0.0117)\end{array}$ & $\begin{array}{c}-0.363^{* * *} \\
(0.127)\end{array}$ & $\begin{array}{l}0.0260^{*} \\
(0.0135)\end{array}$ & $\begin{array}{c}-0.338^{* * *} \\
(0.126)\end{array}$ & $\begin{array}{c}0.0179 \\
(0.0135)\end{array}$ \\
\hline $\begin{array}{c}\text { Trade } \\
\text { Openness }\end{array}$ & $\begin{array}{c}0.00419 \\
(0.00332)\end{array}$ & $\begin{array}{l}-0.0511 \\
(0.0571) \\
\end{array}$ & $\begin{array}{c}0.00412 \\
(0.00333)\end{array}$ & $\begin{array}{l}-0.0485 \\
(0.0565) \\
\end{array}$ & $\begin{array}{c}0.0251^{* * *} \\
(0.00876)\end{array}$ & $\begin{array}{c}-0.0940 \\
(0.107)\end{array}$ & $\begin{array}{c}0.0255^{* * *} \\
(0.00881)\end{array}$ & $\begin{array}{l}-0.125 \\
(0.107)\end{array}$ & $\begin{array}{l}0.0239^{*} \\
(0.0134)\end{array}$ & $\begin{array}{l}0.0144 \\
(0.129)\end{array}$ & $\begin{array}{l}0.0219^{*} \\
(0.0132)\end{array}$ & $\begin{array}{c}-0.0323 \\
(0.129) \\
\end{array}$ \\
\hline Deficit & $\begin{array}{l}-0.0358 \\
(0.0626) \\
\end{array}$ & $\begin{array}{l}-0.0140 * \\
(0.00773)\end{array}$ & $\begin{array}{l}-0.0375 \\
(0.0627) \\
\end{array}$ & $\begin{array}{c}-0.0229 \text { ** } \\
(0.00900)\end{array}$ & $\begin{array}{c}0.0676 \\
(0.0918) \\
\end{array}$ & $\begin{array}{c}-0.0708^{* * *} \\
(0.0166)\end{array}$ & $\begin{array}{c}0.0551 \\
(0.0940)\end{array}$ & $\begin{array}{c}-0.0796^{* * *} \\
(0.0171)\end{array}$ & $\begin{array}{c}0.106 \\
(0.126)\end{array}$ & $\begin{array}{c}-0.0796^{* * *} \\
(0.0197)\end{array}$ & $\begin{array}{l}0.0613 \\
(0.130)\end{array}$ & $\begin{array}{c}-0.0929^{* * *} \\
(0.0205)\end{array}$ \\
\hline Debt & $\begin{array}{c}-0.0324^{* *} \\
(0.0158)\end{array}$ & $\begin{array}{c}0.000733 \\
(0.0609)\end{array}$ & $\begin{array}{c}-0.04511^{* *} \\
(0.0220)\end{array}$ & $\begin{array}{l}-0.0178 \\
(0.0611) \\
\end{array}$ & $\begin{array}{c}-0.0996^{* * *} \\
(0.0287)\end{array}$ & $\begin{array}{l}-0.0336 \\
(0.0832) \\
\end{array}$ & $\begin{array}{c}-0.114^{* * *} \\
(0.0366)\end{array}$ & $\begin{array}{l}-0.0390 \\
(0.0821)\end{array}$ & $\begin{array}{c}-0.187^{* * *} \\
(0.0432)\end{array}$ & $\begin{array}{l}-0.0375 \\
(0.0973) \\
\end{array}$ & $\begin{array}{c}-0.224^{* * *} \\
(0.0477)\end{array}$ & $\begin{array}{l}-0.0636 \\
(0.0948) \\
\end{array}$ \\
\hline CPI or WGI & - & - & $\begin{array}{l}-0.00175 \\
(0.00210)\end{array}$ & $\begin{array}{c}-0.00750 * \\
(0.00402)\end{array}$ & - & - & $\begin{array}{l}-0.00341 \\
(0.00519)\end{array}$ & $\begin{array}{c}-0.0242 * \\
(0.0134)\end{array}$ & - & - & $\begin{array}{l}-0.00989 \\
(0.00612)\end{array}$ & $\begin{array}{c}-0.0311 * \\
(0.0159)\end{array}$ \\
\hline $\begin{array}{c}\text { Debt }^{*} \text { CPI } \\
\text { or WGI }\end{array}$ & $\begin{array}{l}0.00419 * \\
(0.00222)\end{array}$ & $\begin{array}{c}0.00636 \\
(0.00443)\end{array}$ & $\begin{array}{l}0.00609 * \\
(0.00319)\end{array}$ & $\begin{array}{l}0.0136^{* *} \\
(0.00585)\end{array}$ & $\begin{array}{c}0.0116^{* * *} \\
(0.00368)\end{array}$ & $\begin{array}{c}0.0332 * * * \\
(0.00868)\end{array}$ & $\begin{array}{c}0.0139 * * * \\
(0.00510)\end{array}$ & $\begin{array}{c}0.0443 * * * \\
(0.0106)\end{array}$ & $\begin{array}{c}0.0220 * * * \\
(0.00602)\end{array}$ & $\begin{array}{c}0.0387^{* * * *} \\
(0.00979)\end{array}$ & $\begin{array}{c}0.0280 * * * \\
(0.00690)\end{array}$ & $\begin{array}{c}0.0523 * * * \\
(0.0121)\end{array}$ \\
\hline Constant & $\begin{array}{l}0.262 * * * \\
(0.0367)\end{array}$ & $\begin{array}{l}0.290 * * * \\
(0.0352)\end{array}$ & $\begin{array}{l}0.259^{* * *} \\
(0.0370)\end{array}$ & $\begin{array}{c}0.260^{* * *} \\
(0.0383)\end{array}$ & $\begin{array}{c}0.704 * * * \\
(0.0808)\end{array}$ & $\begin{array}{c}0.453^{* * *} \\
(0.110)\end{array}$ & $\begin{array}{l}0.720^{* * *} \\
(0.0842)\end{array}$ & $\begin{array}{c}0.509 * * * \\
(0.113)\end{array}$ & $\begin{array}{c}0.864 * * * \\
(0.152)\end{array}$ & $\begin{array}{c}0.744^{* * *} \\
(0.151)\end{array}$ & $\begin{array}{c}0.872 * * * \\
(0.151)\end{array}$ & $\begin{array}{c}0.749 * * * \\
(0.147)\end{array}$ \\
\hline Observations & 168 & 135 & 168 & 135 & 168 & 135 & 168 & 135 & 89 & 89 & 89 & 89 \\
\hline$R$-squared & 0.260 & 0.456 & 0.263 & 0.471 & 0.501 & 0.399 & 0.503 & 0.422 & & & & \\
\hline
\end{tabular}

Standard errors in parentheses; ${ }^{* * *} p<0.01{ }^{* *} p<0.05,{ }^{*} p<0.1$ 
Table A13. Estimation results: five-year average and 77 countries.

\begin{tabular}{|c|c|c|c|c|c|c|c|c|c|c|c|c|}
\hline & Model (1) & Model (1) & Model (2) & Model (2) & Model (3) & Model (3) & Model (4) & Model (4) & Model (5) & Model (5) & Model (6) & Model (6) \\
\hline Variables & $\underset{\text { CPI }}{\text { OLS }}$ & $\begin{array}{l}\text { OLS } \\
\text { WGI }\end{array}$ & $\begin{array}{l}\text { OLS } \\
\text { CPI }\end{array}$ & $\begin{array}{l}\text { OLS } \\
\text { WGI }\end{array}$ & $\begin{array}{c}\text { Fixed } \\
\text { Effect } \\
\text { CPI }\end{array}$ & $\begin{array}{l}\text { Fixed } \\
\text { Effect } \\
\text { WGI }\end{array}$ & $\begin{array}{c}\text { Fixed } \\
\text { Effect } \\
\text { CPI }\end{array}$ & $\begin{array}{l}\text { Fixed } \\
\text { Effect } \\
\text { WGI }\end{array}$ & $\underset{\text { CPI }}{\text { GMM }}$ & $\begin{array}{c}\text { GMM } \\
\text { WGI }\end{array}$ & $\underset{\text { CPI }}{\text { GMM }}$ & $\begin{array}{c}\text { GMM } \\
\text { WGI }\end{array}$ \\
\hline Initial GDP & $\begin{array}{c}-0.0207 * * * \\
(0.00382)\end{array}$ & $\begin{array}{c}-0.0215^{* * *} \\
(0.00384)\end{array}$ & $\begin{array}{c}-0.0202^{* * *} \\
(0.00390)\end{array}$ & $\begin{array}{c}-0.0204^{* * *} \\
(0.00390)\end{array}$ & $\begin{array}{c}-0.0968^{* * *} \\
(0.0113)\end{array}$ & $\begin{array}{c}-0.0900^{* * * *} \\
(0.0135)\end{array}$ & $\begin{array}{c}-0.0978^{* * *} \\
(0.0113)\end{array}$ & $\begin{array}{c}-0.0894^{* * *} \\
(0.0136)\end{array}$ & $\begin{array}{c}-0.128^{* * *} \\
(0.0174)\end{array}$ & $\begin{array}{c}-0.125^{* * *} \\
(0.0173)\end{array}$ & $\begin{array}{c}-0.130^{* * *} \\
(0.0172)\end{array}$ & $\begin{array}{c}-0.125^{\text {*** }} \\
(0.0173)\end{array}$ \\
\hline $\begin{array}{l}\text { Human } \\
\text { Capital }\end{array}$ & $\begin{array}{c}0.0220^{* * * *} \\
(0.00583)\end{array}$ & $\begin{array}{l}0.0278^{* * *} \\
(0.00589)\end{array}$ & $\begin{array}{c}0.0224 * * * \\
(0.00585)\end{array}$ & $\begin{array}{c}0.0283^{* * * *} \\
(0.00589)\end{array}$ & $\begin{array}{c}0.0849^{* * *} \\
(0.0222)\end{array}$ & $\begin{array}{c}0.0760^{* * *} \\
(0.0258)\end{array}$ & $\begin{array}{c}0.0882 * * * \\
(0.0222)\end{array}$ & $\begin{array}{c}0.0785^{* * *} \\
(0.0263)\end{array}$ & $\begin{array}{l}0.107 * * * \\
(0.0285)\end{array}$ & $\begin{array}{c}0.109 * * * \\
(0.0283)\end{array}$ & $\begin{array}{l}0.111^{* * *} \\
(0.0284)\end{array}$ & $\begin{array}{l}0.108 * * * \\
(0.0290)\end{array}$ \\
\hline Inflation & $\begin{array}{c}0.0223 \\
(0.0547) \\
\end{array}$ & $\begin{array}{l}0.00367 \\
(0.0389) \\
\end{array}$ & $\begin{array}{c}0.0144 \\
(0.0558) \\
\end{array}$ & $\begin{array}{c}-0.000236 \\
(0.0389)\end{array}$ & $\begin{array}{c}-0.128 * * \\
(0.0606)\end{array}$ & $\begin{array}{c}-0.198 \text { ** } \\
(0.0913)\end{array}$ & $\begin{array}{l}-0.0999 \\
(0.0629)\end{array}$ & $\begin{array}{c}-0.190 * * \\
(0.0929)\end{array}$ & $\begin{array}{l}-0.0879 \\
(0.0763) \\
\end{array}$ & $\begin{array}{c}-0.288^{* * *} \\
(0.0951)\end{array}$ & $\begin{array}{l}-0.0504 \\
(0.0798)\end{array}$ & $\begin{array}{c}-0.291^{* * *} \\
(0.0964)\end{array}$ \\
\hline $\begin{array}{l}\text { Government } \\
\text { Size }\end{array}$ & $\begin{array}{c}-0.00844 \\
(0.0373)\end{array}$ & $\begin{array}{l}-0.00326 \\
(0.00395)\end{array}$ & $\begin{array}{l}-0.0113 \\
(0.0375) \\
\end{array}$ & $\begin{array}{l}-0.00225 \\
(0.00401)\end{array}$ & $\begin{array}{c}-0.379 * * * \\
(0.0722)\end{array}$ & $\begin{array}{l}0.0269^{*} \\
(0.0137)\end{array}$ & $\begin{array}{c}-0.364^{* * *} \\
(0.0725)\end{array}$ & $\begin{array}{c}0.0279 \text { ** } \\
(0.0139)\end{array}$ & $\begin{array}{c}-0.321^{* * *} \\
(0.100)\end{array}$ & $\begin{array}{c}0.0327^{* *} \\
(0.0145)\end{array}$ & $\begin{array}{c}-0.308^{* * *} \\
(0.100)\end{array}$ & $\begin{array}{c}0.0319^{* *} \\
(0.0147)\end{array}$ \\
\hline $\begin{array}{c}\text { Trade } \\
\text { Openness }\end{array}$ & $\begin{array}{c}0.00226 \\
(0.00364)\end{array}$ & $\begin{array}{c}-0.0917^{* *} \\
(0.0453)\end{array}$ & $\begin{array}{c}0.00265 \\
(0.00368)\end{array}$ & $\begin{array}{c}-0.0930 * * \\
(0.0452)\end{array}$ & $\begin{array}{c}0.0264 * * * \\
(0.00964)\end{array}$ & $\begin{array}{c}-0.0819 \\
(0.103)\end{array}$ & $\begin{array}{c}0.0253^{* * *} \\
(0.00963)\end{array}$ & $\begin{array}{c}-0.0774 \\
(0.104)\end{array}$ & $\begin{array}{c}0.0341^{* *} \\
(0.0148)\end{array}$ & $\begin{array}{l}0.0228 \\
(0.112)\end{array}$ & $\begin{array}{c}0.0337^{* *} \\
(0.0147)\end{array}$ & $\begin{array}{l}0.0176 \\
(0.112)\end{array}$ \\
\hline Deficit & $\begin{array}{c}-0.0835 * \\
(0.0461)\end{array}$ & $\begin{array}{l}-0.00303 \\
(0.00675)\end{array}$ & $\begin{array}{c}-0.0822 * \\
(0.0462)\end{array}$ & $\begin{array}{l}-0.00531 \\
(0.00693)\end{array}$ & $\begin{array}{c}0.0313 \\
(0.0862)\end{array}$ & $\begin{array}{c}-0.0230 * \\
(0.0122)\end{array}$ & $\begin{array}{c}0.0463 \\
(0.0863) \\
\end{array}$ & $\begin{array}{c}-0.0224 * \\
(0.0123)\end{array}$ & $\begin{array}{l}0.0425 \\
(0.111)\end{array}$ & $\begin{array}{c}-0.0340^{* * * *} \\
(0.0129)\end{array}$ & $\begin{array}{l}0.0541 \\
(0.111)\end{array}$ & $\begin{array}{c}-0.0341^{* * *} \\
(0.0130)\end{array}$ \\
\hline Debt & $\begin{array}{c}-0.00626 \\
(0.0129)\end{array}$ & $\begin{array}{c}0.0495 \\
(0.0565)\end{array}$ & $\begin{array}{l}-0.0135 \\
(0.0162) \\
\end{array}$ & $\begin{array}{c}0.0365 \\
(0.0571)\end{array}$ & $\begin{array}{c}-0.0494 * * \\
(0.0209)\end{array}$ & $\begin{array}{c}-0.144^{* *} \\
(0.0693)\end{array}$ & $\begin{array}{l}-0.0321 \\
(0.0235) \\
\end{array}$ & $\begin{array}{l}-0.139 * \\
(0.0703)\end{array}$ & $\begin{array}{c}-0.0672^{* *} \\
(0.0285)\end{array}$ & $\begin{array}{l}-0.112 \\
(0.0755)\end{array}$ & $\begin{array}{c}-0.0514 * \\
(0.0303)\end{array}$ & $\begin{array}{l}-0.116 \\
(0.0766)\end{array}$ \\
\hline CPI or WGI & - & - & $\begin{array}{l}-0.00138 \\
(0.00186)\end{array}$ & $\begin{array}{l}-0.00545 \\
(0.00389)\end{array}$ & - & $\begin{array}{l}- \\
-\end{array}$ & $\begin{array}{c}0.00706 \\
(0.00445)\end{array}$ & $\begin{array}{l}0.00577 \\
(0.0113)\end{array}$ & - & - & $\begin{array}{c}0.00793 \\
(0.00517)\end{array}$ & $\begin{array}{c}-0.00320 \\
(0.0120)\end{array}$ \\
\hline $\begin{array}{c}\text { Debt }^{*} \text { CPI } \\
\text { or WGI }\end{array}$ & $\begin{array}{l}0.000463 \\
(0.00206)\end{array}$ & $\begin{array}{l}-0.00407 \\
(0.00441)\end{array}$ & $\begin{array}{c}0.00179 \\
(0.00273)\end{array}$ & $\begin{array}{l}0.000772 \\
(0.00559)\end{array}$ & $\begin{array}{l}0.00599 * \\
(0.00341)\end{array}$ & $\begin{array}{c}0.00801 \\
(0.00914)\end{array}$ & $\begin{array}{c}0.00243 \\
(0.00407)\end{array}$ & $\begin{array}{l}0.00552 \\
(0.0104) \\
\end{array}$ & $\begin{array}{c}0.00686 \\
(0.00522)\end{array}$ & $\begin{array}{c}0.00567 \\
(0.00969)\end{array}$ & $\begin{array}{c}0.00337 \\
(0.00569)\end{array}$ & $\begin{array}{l}0.00684 \\
(0.0110) \\
\end{array}$ \\
\hline Constant & $\begin{array}{l}0.167^{* * *} \\
(0.0284)\end{array}$ & $\begin{array}{l}0.158^{* * *} \\
(0.0288)\end{array}$ & $\begin{array}{l}0.169 * * * \\
(0.0286)\end{array}$ & $\begin{array}{l}0.150 * * * \\
(0.0293)\end{array}$ & $\begin{array}{c}0.777^{* * *} \\
(0.0781)\end{array}$ & $\begin{array}{c}0.705^{* * *} \\
(0.102)\end{array}$ & $\begin{array}{c}0.737^{* * *} \\
(0.0817) \\
\end{array}$ & $\begin{array}{c}0.689 * * * \\
(0.107) \\
\end{array}$ & $\begin{array}{c}1.005^{* * *} \\
(0.125) \\
\end{array}$ & $\begin{array}{c}0.963^{* * *} \\
(0.122) \\
\end{array}$ & $\begin{array}{c}0.967^{* * *} \\
(0.128) \\
\end{array}$ & $\begin{array}{c}0.968^{* * *} \\
(0.126) \\
\end{array}$ \\
\hline Observations & 257 & 223 & 257 & 223 & 257 & 223 & 257 & 223 & 143 & 146 & 143 & 146 \\
\hline$R$-squared & 0.143 & 0.236 & 0.145 & 0.243 & 0.406 & 0.304 & 0.415 & 0.305 & & & & \\
\hline
\end{tabular}

Standard errors in parentheses; ${ }^{* * *} p<0.01{ }^{* *} p<0.05,{ }^{*} p<0.1$. 
Table A14. Estimation results: ten-year average and 38 countries.

\begin{tabular}{|c|c|c|c|c|c|c|c|c|}
\hline & Model (1) & Model (1) & Model (2) & Model (2) & Model (3) & Model (3) & Model (4) & Model (4) \\
\hline Variables & $\begin{array}{l}\text { OLS } \\
\text { CPI }\end{array}$ & $\begin{array}{l}\text { OLS } \\
\text { WGI }\end{array}$ & $\begin{array}{l}\text { OLS } \\
\text { CPI }\end{array}$ & $\begin{array}{l}\text { OLS } \\
\text { WGI }\end{array}$ & $\begin{array}{l}\text { Fixed Effect } \\
\text { CPI }\end{array}$ & $\begin{array}{c}\text { Fixed Effect } \\
\text { WGI }\end{array}$ & $\begin{array}{l}\text { Fixed Effect } \\
\text { CPI }\end{array}$ & $\begin{array}{c}\text { Fixed Effect } \\
\text { WGI }\end{array}$ \\
\hline Initial GDP & $\begin{array}{l}0.717^{* * *} \\
(0.0507)\end{array}$ & $\begin{array}{l}0.722^{* * *} \\
(0.0516)\end{array}$ & $\begin{array}{l}0.740^{* * *} \\
(0.0566)\end{array}$ & $\begin{array}{l}0.757^{* * *} \\
(0.0577)\end{array}$ & $\begin{array}{c}0.598^{* * *} \\
(0.166)\end{array}$ & $\begin{array}{c}0.547^{* * *} \\
(0.161)\end{array}$ & $\begin{array}{c}0.613^{* * *} \\
(0.172)\end{array}$ & $\begin{array}{c}0.555^{* * *} \\
(0.172)\end{array}$ \\
\hline Human Capital & $\begin{array}{c}0.0330 \\
(0.0702)\end{array}$ & $\begin{array}{c}0.0434 \\
(0.0714)\end{array}$ & $\begin{array}{c}0.0243 \\
(0.0709)\end{array}$ & $\begin{array}{c}0.0313 \\
(0.0715)\end{array}$ & $\begin{array}{c}0.774^{* * *} \\
(0.268)\end{array}$ & $\begin{array}{c}0.937^{* * *} \\
(0.264)\end{array}$ & $\begin{array}{c}0.808^{* *} \\
(0.280)\end{array}$ & $\begin{array}{c}0.935^{* * *} \\
(0.271)\end{array}$ \\
\hline Inflation & $\begin{array}{c}0.738 \\
(1.104)\end{array}$ & $\begin{array}{c}-0.0239 \\
(0.464)\end{array}$ & $\begin{array}{c}0.556 \\
(1.124)\end{array}$ & $\begin{array}{l}-0.161 \\
(0.472)\end{array}$ & $\begin{array}{c}0.923 \\
(1.185)\end{array}$ & $\begin{array}{c}-4.253^{* * *} \\
(1.252)\end{array}$ & $\begin{array}{c}0.386 \\
(1.568)\end{array}$ & $\begin{array}{c}-4.237^{* * *} \\
(1.290)\end{array}$ \\
\hline Government Size & $\begin{array}{c}-0.00974 \\
(0.455)\end{array}$ & $\begin{array}{l}-0.0384 \\
(0.0388)\end{array}$ & $\begin{array}{l}-0.101 \\
(0.467)\end{array}$ & $\begin{array}{l}-0.0333 \\
(0.0387)\end{array}$ & $\begin{array}{c}-3.292 * * \\
(1.416)\end{array}$ & $\begin{array}{l}-0.136 \\
(0.140)\end{array}$ & $\begin{array}{c}-3.212 * * \\
(1.452)\end{array}$ & $\begin{array}{l}-0.146 \\
(0.155)\end{array}$ \\
\hline Trade Openness & $\begin{array}{l}-0.0397 \\
(0.0381)\end{array}$ & $\begin{array}{l}-0.150 \\
(1.104)\end{array}$ & $\begin{array}{l}-0.0378 \\
(0.0382) \\
\end{array}$ & $\begin{array}{c}0.289 \\
(1.145)\end{array}$ & $\begin{array}{l}-0.109 \\
(0.136)\end{array}$ & $\begin{array}{l}-2.572 \\
(1.790)\end{array}$ & $\begin{array}{l}-0.142 \\
(0.151)\end{array}$ & $\begin{array}{l}-2.635 \\
(1.879)\end{array}$ \\
\hline Deficit & $\begin{array}{l}0.0125 \\
(1.088) \\
\end{array}$ & $\begin{array}{l}-0.176 * \\
(0.0993)\end{array}$ & $\begin{array}{c}0.282 \\
(1.130) \\
\end{array}$ & $\begin{array}{c}-0.280^{* *} \\
(0.126)\end{array}$ & $\begin{array}{l}-3.129 \\
(1.824) \\
\end{array}$ & $\begin{array}{l}-0.321 \\
(0.192) \\
\end{array}$ & $\begin{array}{c}-3.305^{*} \\
(1.890) \\
\end{array}$ & $\begin{array}{l}-0.349 \\
(0.259) \\
\end{array}$ \\
\hline Debt & $\begin{array}{c}-0.420^{* *} \\
(0.178)\end{array}$ & $\begin{array}{c}0.502 \\
(1.110) \\
\end{array}$ & $\begin{array}{c}-0.597^{* *} \\
(0.265)\end{array}$ & $\begin{array}{c}0.331 \\
(1.110) \\
\end{array}$ & $\begin{array}{c}-1.077^{* *} \\
(0.421)\end{array}$ & $\begin{array}{l}-0.173 \\
(1.294) \\
\end{array}$ & $\begin{array}{c}-1.334 \\
(0.643)\end{array}$ & $\begin{array}{l}-0.247 \\
(1.400) \\
\end{array}$ \\
\hline CPI or WGI & - & - & $\begin{array}{l}-0.0226 \\
(0.0251)\end{array}$ & $\begin{array}{l}-0.0668 \\
(0.0503)\end{array}$ & - & - & $\begin{array}{l}-0.0331 \\
(0.0616)\end{array}$ & $\begin{array}{c}-0.0226 \\
(0.133)\end{array}$ \\
\hline Debt ${ }^{*}$ CPI or WGI & $\begin{array}{c}0.0485^{* *} \\
(0.0236)\end{array}$ & $\begin{array}{c}0.0679 \\
(0.0463) \\
\end{array}$ & $\begin{array}{l}0.0730 \text { ** } \\
(0.0361)\end{array}$ & $\begin{array}{c}0.139^{*} \\
(0.0707)\end{array}$ & $\begin{array}{l}0.136^{* *} \\
(0.0475)\end{array}$ & $\begin{array}{l}0.190^{* *} \\
(0.0680)\end{array}$ & $\begin{array}{l}0.170^{* *} \\
(0.0794)\end{array}$ & $\begin{array}{c}0.208 \\
(0.127)\end{array}$ \\
\hline Constant & $\begin{array}{c}1.920 * * * \\
(0.393)\end{array}$ & $\begin{array}{c}1.849^{* * *} \\
(0.401)\end{array}$ & $\begin{array}{c}1.890^{* * *} \\
(0.395)\end{array}$ & $\begin{array}{c}1.634^{* * *} \\
(0.430)\end{array}$ & $\begin{array}{c}1.665 \\
(1.205) \\
\end{array}$ & $\begin{array}{c}1.845 \\
(1.188)\end{array}$ & $\begin{array}{c}1.683 \\
(1.230)\end{array}$ & $\begin{array}{c}1.807 \\
(1.242)\end{array}$ \\
\hline Observations & 64 & 64 & 64 & 64 & 64 & 64 & 64 & 64 \\
\hline$R$-squared & 0.953 & 0.951 & 0.954 & 0.953 & 0.916 & 0.915 & 0.918 & 0.915 \\
\hline
\end{tabular}


Table A15. Estimation results: ten-year average and 46 countries.

\begin{tabular}{|c|c|c|c|c|c|c|c|c|}
\hline & Model (1) & Model (1) & Model (2) & Model (2) & Model (3) & Model (3) & Model (4) & Model (4) \\
\hline Variables & $\begin{array}{l}\text { OLS } \\
\text { CPI }\end{array}$ & $\begin{array}{l}\text { OLS } \\
\text { WGI }\end{array}$ & $\begin{array}{l}\text { OLS } \\
\text { CPI }\end{array}$ & $\begin{array}{l}\text { OLS } \\
\text { WGI }\end{array}$ & $\begin{array}{c}\text { Fixed Effect } \\
\text { CPI }\end{array}$ & $\begin{array}{c}\text { Fixed Effect } \\
\text { WGI }\end{array}$ & $\begin{array}{c}\text { Fixed Effect } \\
\text { CPI }\end{array}$ & $\begin{array}{c}\text { Fixed Effect } \\
\text { WGI }\end{array}$ \\
\hline Initial GDP & $\begin{array}{l}0.675^{* * *} \\
(0.0464)\end{array}$ & $\begin{array}{l}0.679 * * * \\
(0.0473)\end{array}$ & $\begin{array}{c}0.683^{* * *} \\
(0.0503)\end{array}$ & $\begin{array}{l}0.697^{* * *} \\
(0.0515)\end{array}$ & $\begin{array}{c}0.204 \\
(0.150)\end{array}$ & $\begin{array}{c}0.119 \\
(0.153)\end{array}$ & $\begin{array}{c}0.222 \\
(0.150)\end{array}$ & $\begin{array}{l}0.0960 \\
(0.159)\end{array}$ \\
\hline Human Capital & $\begin{array}{c}0.0310 \\
(0.0698)\end{array}$ & $\begin{array}{l}0.0387 \\
(0.0709)\end{array}$ & $\begin{array}{c}0.0261 \\
(0.0710)\end{array}$ & $\begin{array}{c}0.0304 \\
(0.0716)\end{array}$ & $\begin{array}{c}0.840^{* *} \\
(0.307)\end{array}$ & $\begin{array}{c}0.935^{* * *} \\
(0.330)\end{array}$ & $\begin{array}{l}0.775^{* *} \\
(0.310)\end{array}$ & $\begin{array}{c}0.979 * * * \\
(0.342)\end{array}$ \\
\hline Inflation & $\begin{array}{c}1.169 \\
(1.084)\end{array}$ & $\begin{array}{l}-0.302 \\
(0.434)\end{array}$ & $\begin{array}{c}1.052 \\
(1.120)\end{array}$ & $\begin{array}{l}-0.285 \\
(0.435)\end{array}$ & $\begin{array}{c}1.505 \\
(1.338)\end{array}$ & $\begin{array}{c}-3.960^{* * *} \\
(1.192)\end{array}$ & $\begin{array}{c}2.874 \\
(1.773)\end{array}$ & $\begin{array}{c}-4.004^{* * *} \\
(1.209)\end{array}$ \\
\hline Government Size & $\begin{array}{l}-0.306 \\
(0.427)\end{array}$ & $\begin{array}{c}0.0304 \\
(0.0335)\end{array}$ & $\begin{array}{l}-0.297 \\
(0.430)\end{array}$ & $\begin{array}{l}0.0300 \\
(0.0335)\end{array}$ & $\begin{array}{c}-3.151 \text { ** } \\
(1.203)\end{array}$ & $\begin{array}{c}0.212 \\
(0.125)\end{array}$ & $\begin{array}{c}-3.345^{* *} \\
(1.206)\end{array}$ & $\begin{array}{l}0.233^{*} \\
(0.131)\end{array}$ \\
\hline Trade Openness & $\begin{array}{c}0.0265 \\
(0.0330)\end{array}$ & $\begin{array}{l}-1.083 \\
(0.693)\end{array}$ & $\begin{array}{c}0.0255 \\
(0.0332)\end{array}$ & $\begin{array}{l}-1.078 \\
(0.694)\end{array}$ & $\begin{array}{c}0.200 \\
(0.118)\end{array}$ & $\begin{array}{l}-0.555 \\
(1.340)\end{array}$ & $\begin{array}{l}0.237^{*} \\
(0.121)\end{array}$ & $\begin{array}{l}-0.353 \\
(1.394)\end{array}$ \\
\hline Deficit & $\begin{array}{l}-0.982 \\
(0.683)\end{array}$ & $\begin{array}{l}-0.105 \\
(0.0883)\end{array}$ & $\begin{array}{l}-0.985 \\
(0.687)\end{array}$ & $\begin{array}{l}-0.159 \\
(0.107)\end{array}$ & $\begin{array}{l}-0.648 \\
(1.258)\end{array}$ & $\begin{array}{l}-0.256 \\
(0.250)\end{array}$ & $\begin{array}{l}-0.387 \\
(1.269)\end{array}$ & $\begin{array}{l}-0.135 \\
(0.317)\end{array}$ \\
\hline Debt & $\begin{array}{c}-0.376^{* *} \\
(0.170)\end{array}$ & $\begin{array}{c}0.866 \\
(1.084)\end{array}$ & $\begin{array}{c}-0.455^{*} \\
(0.242)\end{array}$ & $\begin{array}{c}0.682 \\
(1.105)\end{array}$ & $\begin{array}{c}-1.093 \text { ** } \\
(0.496)\end{array}$ & $\begin{array}{c}0.770 \\
(1.472)\end{array}$ & $\begin{array}{l}-0.457 \\
(0.735)\end{array}$ & $\begin{array}{c}1.174 \\
(1.623)\end{array}$ \\
\hline CPI or WGI & $\begin{array}{l}- \\
-\end{array}$ & - & $\begin{array}{l}-0.0102 \\
(0.0223)\end{array}$ & $\begin{array}{l}-0.0404 \\
(0.0453)\end{array}$ & $\begin{array}{l}- \\
-\end{array}$ & $\begin{array}{l}- \\
-\end{array}$ & $\begin{array}{c}0.0810 \\
(0.0695)\end{array}$ & $\begin{array}{c}0.105 \\
(0.168)\end{array}$ \\
\hline Debt $^{*} \mathrm{CPI}$ or WGI & $\begin{array}{c}0.0555^{* *} \\
(0.0236)\end{array}$ & $\begin{array}{l}0.0814^{*} \\
(0.0466)\end{array}$ & $\begin{array}{l}0.0671^{*} \\
(0.0346)\end{array}$ & $\begin{array}{l}0.125^{*} \\
(0.0673)\end{array}$ & $\begin{array}{l}0.129^{* *} \\
(0.0571)\end{array}$ & $\begin{array}{c}0.113 \\
(0.0900)\end{array}$ & $\begin{array}{c}0.0450 \\
(0.0917)\end{array}$ & $\begin{array}{l}0.0303 \\
(0.160)\end{array}$ \\
\hline Constant & $\begin{array}{c}2.309^{* * *} \\
(0.365)\end{array}$ & $\begin{array}{c}2.249^{* * *} \\
(0.375)\end{array}$ & $\begin{array}{c}2.310^{* * *} \\
(0.367)\end{array}$ & $\begin{array}{c}2.146^{* * *} \\
(0.393)\end{array}$ & $\begin{array}{c}5.007^{* * *} \\
(0.959)\end{array}$ & $\begin{array}{c}5.639^{* * *} \\
(0.951)\end{array}$ & $\begin{array}{c}4.396^{* * *} \\
(1.086)\end{array}$ & $\begin{array}{c}5.575^{* * *} \\
(0.969)\end{array}$ \\
\hline Observations & 79 & 79 & 79 & 79 & 79 & 79 & 79 & 79 \\
\hline$R$-squared & 0.943 & 0.941 & 0.943 & 0.942 & 0.832 & 0.810 & 0.841 & 0.813 \\
\hline
\end{tabular}


Table A16. Estimation results: ten-year average and 77 countries.

\begin{tabular}{|c|c|c|c|c|c|c|c|c|}
\hline & Model (1) & Model (1) & Model (2) & Model (2) & Model (3) & Model (3) & Model (4) & Model (4) \\
\hline Variables & $\begin{array}{l}\text { OLS } \\
\text { CPI }\end{array}$ & $\begin{array}{l}\text { OLS } \\
\text { WGI }\end{array}$ & $\begin{array}{l}\text { OLS } \\
\text { CPI }\end{array}$ & $\begin{array}{c}\text { OLS } \\
\text { WGI }\end{array}$ & $\begin{array}{c}\text { Fixed Effect } \\
\text { CPI }\end{array}$ & $\begin{array}{c}\text { Fixed Effect } \\
\text { WGI }\end{array}$ & $\begin{array}{c}\text { Fixed Effect } \\
\text { CPI }\end{array}$ & $\begin{array}{c}\text { Fixed Effect } \\
\text { WGI }\end{array}$ \\
\hline Initial GDP & $\begin{array}{l}0.673^{* * *} \\
(0.0384)\end{array}$ & $\begin{array}{l}0.680^{* * *} \\
(0.0377)\end{array}$ & $\begin{array}{l}0.673^{* * *} \\
(0.0389)\end{array}$ & $\begin{array}{c}0.682 * * * \\
(0.0381)\end{array}$ & $\begin{array}{c}0.105 \\
(0.128)\end{array}$ & $\begin{array}{c}0.109 \\
(0.136)\end{array}$ & $\begin{array}{c}0.119 \\
(0.140)\end{array}$ & $\begin{array}{c}0.124 \\
(0.141)\end{array}$ \\
\hline Human Capital & $\begin{array}{l}0.242^{* * *} \\
(0.0603)\end{array}$ & $\begin{array}{l}0.254^{* * *} \\
(0.0589)\end{array}$ & $\begin{array}{c}0.243^{* * *} \\
(0.0614)\end{array}$ & $\begin{array}{c}0.256^{* * *} \\
(0.0599)\end{array}$ & $\begin{array}{c}0.857^{* * *} \\
(0.279)\end{array}$ & $\begin{array}{c}0.877^{* * *} \\
(0.293)\end{array}$ & $\begin{array}{c}0.844^{* * *} \\
(0.287)\end{array}$ & $\begin{array}{c}0.879 \text { *** } \\
(0.296)\end{array}$ \\
\hline Inflation & $\begin{array}{c}-0.0299 \\
(0.710)\end{array}$ & $\begin{array}{l}-0.308 \\
(0.402)\end{array}$ & $\begin{array}{c}-0.0350 \\
(0.715)\end{array}$ & $\begin{array}{l}-0.314 \\
(0.404)\end{array}$ & $\begin{array}{l}-0.134 \\
(1.153)\end{array}$ & $\begin{array}{c}-3.284^{* * *} \\
(0.806)\end{array}$ & $\begin{array}{c}-0.0401 \\
(1.219)\end{array}$ & $\begin{array}{c}-3.172 * * * \\
(0.851)\end{array}$ \\
\hline Government Size & $\begin{array}{l}-0.236 \\
(0.403)\end{array}$ & $\begin{array}{c}0.0333 \\
(0.0378)\end{array}$ & $\begin{array}{l}-0.240 \\
(0.407)\end{array}$ & $\begin{array}{c}0.0345 \\
(0.0383)\end{array}$ & $\begin{array}{c}-4.134^{* * *} \\
(0.855)\end{array}$ & $\begin{array}{c}0.141 \\
(0.120)\end{array}$ & $\begin{array}{c}-4.011^{* * *} \\
(0.977)\end{array}$ & $\begin{array}{c}0.144 \\
(0.121)\end{array}$ \\
\hline Trade Openness & $\begin{array}{c}0.0337 \\
(0.0380)\end{array}$ & $\begin{array}{c}-1.110^{* *} \\
(0.497)\end{array}$ & $\begin{array}{c}0.0342 \\
(0.0384)\end{array}$ & $\begin{array}{c}-1.114 \text { ** } \\
(0.500)\end{array}$ & $\begin{array}{c}0.173 \\
(0.114)\end{array}$ & $\begin{array}{c}0.554 \\
(0.988)\end{array}$ & $\begin{array}{c}0.170 \\
(0.116)\end{array}$ & $\begin{array}{c}0.449 \\
(1.025)\end{array}$ \\
\hline Deficit & $\begin{array}{c}-1.143 \text { ** } \\
(0.502)\end{array}$ & $\begin{array}{c}0.0316 \\
(0.0681) \\
\end{array}$ & $\begin{array}{c}-1.144^{* *} \\
(0.505)\end{array}$ & $\begin{array}{c}0.0283 \\
(0.0698) \\
\end{array}$ & $\begin{array}{c}1.376 \\
(0.965)\end{array}$ & $\begin{array}{c}-0.271 \text { ** } \\
(0.121)\end{array}$ & $\begin{array}{c}1.369 \\
(0.978)\end{array}$ & $\begin{array}{c}-0.258^{* *} \\
(0.126)\end{array}$ \\
\hline Debt & $\begin{array}{l}0.0238 \\
(0.143)\end{array}$ & $\begin{array}{l}-0.189 \\
(0.704)\end{array}$ & $\begin{array}{l}0.0128 \\
(0.176)\end{array}$ & $\begin{array}{l}-0.198 \\
(0.708)\end{array}$ & $\begin{array}{c}-0.715^{* *} \\
(0.269)\end{array}$ & $\begin{array}{l}-0.443 \\
(1.174)\end{array}$ & $\begin{array}{c}-0.688^{* *} \\
(0.290)\end{array}$ & $\begin{array}{l}-0.383 \\
(1.193)\end{array}$ \\
\hline CPI or WGI & $\begin{array}{l}- \\
-\end{array}$ & - & $\begin{array}{c}-0.00213 \\
(0.0198)\end{array}$ & $\begin{array}{c}-0.00904 \\
(0.0384)\end{array}$ & $\begin{array}{l}- \\
-\end{array}$ & $\begin{array}{l}- \\
-\end{array}$ & $\begin{array}{c}0.0133 \\
(0.0493)\end{array}$ & $\begin{array}{c}0.0452 \\
(0.0999)\end{array}$ \\
\hline Debt*CPI or WGI & $\begin{array}{c}-2.01 \times 10^{-5} \\
(0.0231)\end{array}$ & $\begin{array}{l}-0.0167 \\
(0.0442)\end{array}$ & $\begin{array}{l}0.00205 \\
(0.0302)\end{array}$ & $\begin{array}{c}-0.00836 \\
(0.0568)\end{array}$ & $\begin{array}{l}0.0767^{*} \\
(0.0418)\end{array}$ & $\begin{array}{c}0.0838 \\
(0.0687)\end{array}$ & $\begin{array}{c}0.0700 \\
(0.0491)\end{array}$ & $\begin{array}{c}0.0581 \\
(0.0896)\end{array}$ \\
\hline Constant & $\begin{array}{c}1.669^{* * *} \\
(0.289)\end{array}$ & $\begin{array}{c}1.581^{* * *} \\
(0.285)\end{array}$ & $\begin{array}{c}1.673^{* * *} \\
(0.293)\end{array}$ & $\begin{array}{c}1.570 * * * \\
(0.290)\end{array}$ & $\begin{array}{c}6.066^{* * *} \\
(0.782)\end{array}$ & $\begin{array}{c}5.823^{* * *} \\
(0.821)\end{array}$ & $\begin{array}{c}5.880^{* * *} \\
(1.050)\end{array}$ & $\begin{array}{c}5.635^{* * *} \\
(0.927)\end{array}$ \\
\hline Observations & 121 & 124 & 121 & 124 & 121 & 124 & 121 & 124 \\
\hline$R$-squared & 0.946 & 0.949 & 0.946 & 0.949 & 0.776 & 0.737 & 0.776 & 0.738 \\
\hline
\end{tabular}

Standard errors in parentheses; ${ }^{* * *} p<0.01,{ }^{* *} p<0.05,{ }^{*} p<0.1$. 


\section{References}

1. Rogoff, K.; Reinhart, C. Growth in a Time of Debt. Am. Econ. Rev. 2010, 100, 573-578.

2. Keen, S. Household Debt: The Final Stage in an Artificially Extended Ponzi Bubble. Aust. Econ. Rev. 2009, 42, 347-357. [CrossRef]

3. Hien, E.; van Treeck, T. Financialisation in Post-Keynesian Models of Distribution and Growth-A Systematic Review; IMK Working Paper 20/2008; Macroeconomic Policy Institute: Düsseldorf, Germany, 2008.

4. Arellano, M.; Bond, S. Some Tests of Specification for Panel Data: Monte Carlo Evidence and Application to Employment Equations. Rev. Econ. Stud. 1991, 58, 277-297. [CrossRef]

5. Jalles, T.J. The impact of democracy and corruption on the debt-growth relationship in developing countries. J. Econ. Dev. 2011, 36, 41-72.

6. Mankiw, G.N.; Elmendorf, D.W. Government Debt. In Handbook of Macroeconomics; Elsevier: New York, NY, USA, 1999.

7. Barro, R.J. Are government bonds net wealth? J. Political Econ. 1974, 82, 1095-1117. [CrossRef]

8. Barsky, R.B.; Mankiw, G.N.; Zeldes, S.P. Ricardian Consumers with Keynesian Propensities. Am. Econ. Rev. 1986, 76, 676-691.

9. Feldstein, M. The Effects of Fiscal Policies when Incomes Are Uncertain: A Contradiction to Ricardian Equivalence. Am. Econ. Rev. 1988, 78, 14-23.

10. Hayford, M. Liquidity Constraints and the Ricardian Equivalence Theorem: A Note. J. Money Credit Bank. 1989, 21, 380-387. [CrossRef]

11. Kotlikoff, L.J.; Razin, A.; Rosenthal, W.A. A Strategic Altruistic Model in which Ricardian Equivalence Does Not Hold. Econ. J. 1990, 100, 1261-1268.

12. Leiderman, L.; Razin, A. Testing Ricardian Neutrality with an Intertemporal Stochastic Model. J. Money Credit Bank. 1988, 20, 1-21. [CrossRef]

13. Evans, P. Are Consumers Ricardian? Evidence for the United States. J. Political Econ. 1988, 96, 983-1004. [CrossRef]

14. Evans, P. Is Ricardian Equivalence a Good Approximation? Econ. Inq. 1991, 29, 626-644. [CrossRef]

15. Haug, A.A. Ricardian Equivalence, Rational Expectations, and the Permanent Income Hypothesis. J. Money Credit Bank. 1990, 22, 305-326. [CrossRef]

16. Batdelger, T.; Kandil, M. Determinants of the current account balance in the United States. Appl. Econ. 2012, 44, 653-669. [CrossRef]

17. Craig, S.G.; Hoang, E.C.; Vollrath, D. Household Response to Government Debt: Evidence from Life Insurance Holdings. J. Money Credit Bank. 2015, 47, 819-845. [CrossRef]

18. Linnemann, L.; Schabert, A. Debt Non-neutrality, Policy Interactions, and Macroeconomic Stability. Int. Econ. Rev. 2010, 51, 461-474. [CrossRef]

19. Boyer, R. The Four Fallacies of Contemporary Austerity Policies: The Lost Keynesian Legacy. Camb. J. Econ. 2012, 36, 283-312. [CrossRef]

20. Banzhaf, S.H.; Oates, W.E. On Fiscal Illusion in Local Public Finance: Re-examining Ricardian Equivalence and the Renter Effect. Natl. Tax J. 2013, 66, 511-540. [CrossRef]

21. Evans, G.W.; Honkapohja, S.; Mitra, K. Does Ricardian Equivalence Hold When Expectations Are Not Rational? J. Money Credit Bank. 2012, 44, 1259-1283. [CrossRef]

22. Wong, W.K. Consumption Response to Government Transfers: Behavioral Motives Revealed by Savers and Spenders. Contemp. Econ. Policy 2012, 30, 489-501. [CrossRef]

23. De Castro, F.; Fernández, L. The Effects of Fiscal Shocks on the Exchange Rate in Spain. Econ. Soc. Rev. 2013, 44, 151-180. [CrossRef]

24. Konya, L.; Abdullaev, B. Does Ricardian Equivalence Hold in Australia? A Revision Based on Testing Super Exogeneity with Impulse-Indicator Saturation. Empir. Econ. 2014, 49, 423-448. [CrossRef]

25. Dumiter, F.; Berlingher, D.; Anca, O.; Todor, S. Double taxation conventions, structure and evolution of the American tax system. J. Leg. Stud. 2016, 17, 1-14. [CrossRef]

26. Choi, D.F.S.; Holmes, M.J. Budget Deficits and Real Interest Rates: A Regime-Switching Reflection on Ricardian Equivalence. J. Econ. Financ. 2014, 38, 71-83. [CrossRef]

27. Gale, W.G.; Orszag, P.R. The Economic Effects of Long-Term Fiscal Discipline; Urban-Brookings Tax Policy Center Discussion Paper; Urban Institute: Washington, DC, USA, 2002. 
28. Baldacci, E.; Kumar, M. Fiscal Deficits, Public Debt, and Sovereign Bond Yields; IMF Working Paper; IMF: Washington, DC, USA, 2010.

29. Corsetti, G.; Kuester, K.; Meier, A.; Müller, G.J. Sovereign Risk, Fiscal Policy, and Macroeconomic Stability. Econ. J. 2013, 123, 99-132. [CrossRef]

30. Barro, R.J. On the Determination of the Public Debt. J. Political Econ. 1979, 87, 940-971. [CrossRef]

31. Dotsey, M. Some Unpleasant Supply side Arithmetic. J. Monet. Econ. 1994, 33, 507-524. [CrossRef]

32. Aizenman, J.; Kletzer, K.; Pinto, B. Economic Growth with Constraints on Tax Revenues and Public Debt: Implications for Fiscal Policy and Cross-Country Differences; NBER Working Paper; NBER: Cambridge, MA, USA, 2007.

33. Sargent, T.J.; Wallace, N. Some Unpleasant Monetarist Arithmetic. Fed. Reserv. Bank Minneap. Q. Rev. 1981, 5, 1-17.

34. Barro, R.J. Inflation and Economic Growth; Quarterly Bulletin; Bank of England: London, UK, 1995.

35. Cochrane, J.H. Determinacy and Identification with Taylor Rules. J. Political Econ. 2011, 119, 565-615. [CrossRef]

36. Aghion, P.; Kharroubi, E. Cyclical Macro Policy and Industry Growth: The Effect of Counter-Cyclical Fiscal Policy; Harvard University: Cambridge, MA, USA, 2007.

37. Woo, J. Why Do More Polarized Countries Run More Procyclical Fiscal Policy? Rev. Econ. Stat. 2009, 91, 850-870. [CrossRef]

38. Burnside, C.; Eichenhaum, M.; Rebelo, S. On the Fiscal Implications of Twin Crises; NBER Working Paper; NBER: Cambridge, MA, USA, 2001.

39. Hemming, R.; Kell, M.; Schimmelpgenning, A. Fiscal Vulnerability and Financial Crises in Emerging Market Economics; IMF Working Paper; IMF: Washington, DC, USA, 2003.

40. Curutchet, A.S. Debt and Economic Growth in Developing and Industrial Countries; Working Papers No. 34; Lund University: Lund, Sweden, 2005.

41. Caner, M.; Grennes, T.; Koehler-Geib, F. Finding the Tipping Point-When Sovereign Debt Turns Bad; Policy Research Working Paper 5391; The World Bank: Washington, DC, USA, 2010.

42. Ursua, J.; Wilson, D. Risks to Growth from Build-Ups in Public Debt. Global Economics Weekly; The World Bank: Washington, DC, USA, 2012.

43. Checherita, C.; Rother, P. The Impact of High and Growing Government Debt on Economic Growth: An Empirical Investigation for the Euro Area; Working paper 1237; European Central Bank: Frankfurt, Germany, 2010.

44. Baum, A.; Checherita-Westphal, C.; Rother, P. Debt and Growth: New Evidence for the Euro Area; Working Paper 184; European Central Bank: Frankfurt, Germany, 2012.

45. Cecheritti, S.G.; Mohanty, M.S.; Zampolli, F. The Real Effects of Debt. Bank for International Settlements; Working Paper 352; Bank for International Settlements: Basel, Switzerland, 2012.

46. Panizza, U.; Presbitero, A.F. Public Debt and Economic Growth: Is There a Causal Effect? Università Politecnica delle Marche, MoFiR (Money and Finance Research Group): London, UK, 2012.

47. Balassone, F.; Francese, M.; Pace, A. Public Debt and Economic Growth in Italy; Economic History Working Papers No. 11; Banca d'Ltalia: Rome, Italy, 2011.

48. Casni, A.C.; Badurina, A.A.; Sertic, M.B. Public Debt and Growth: Evidence from Central, Eastern and Southern European countries. Proc. Rij. Fac. Econ. J. Econ. Bus. 2014, 32, 35-51.

49. Woo, J.; Kumar, M.S. Public Debt and Growth. Economica 2015, 82, 705-739. [CrossRef]

50. Modigliani, F.; Fitoussi, J.P.; Moro, B.; Snower, D.; Solow, R.; Steinherr, A.; Labini, P. 'An economists' manifesto on unemployment in the European Union. Banca Naz. Lav. Q. Rev. 1998, 51, 327-361. [CrossRef]

51. Creel, J.; Fitoussi, J.P. How to Reform the European Central Bank; Centre for European Reform: London, UK, 2002.

52. Le Cacheux, J. A golden rule for the euro area? In Proceedings of the CDC-IXIS \& CEPII Fiscal Discipline Workshop, Paris, France, 27 November 2002.

53. Blanchard, O.; Giavazzi, F. Improving the SGP through a Proper Accounting of Public Investment; Discussion Paper No. 4220; Centre for Economic Policy Research (CEPR): London, UK, 2004.

54. Balassone, F.; Franco, D. Public investment, the Stability Pact and the golden rule. Fisc. Stud. 2000, 21, 207-229. [CrossRef]

55. Buiter, W. Notes on a Code for Fiscal Stability. Oxf. Econ. Pap. 2001, 53, 1-9. [CrossRef] 
56. Buti, M.; Eijffinger, S.; Franco, D. Revisiting the SGP: Grand Design or Internal Adjustment? Discussion Paper No. 3692; Centre for Economic Policy Research (CEPR): London, UK, 2003.

57. Minea, A.; Villieu, P. Borrowing to Finance Public Investment? The Golden Rule of Public Finance Reconsidered in an Endogenous Growth Setting. Fisc. Stud. 2009, 30, 103-133. [CrossRef]

58. Pattillo, C.; Poirson, H.; Ricci, L.A. External Debt and Growth. Rev. Econ. Inst. 2011, 2, 1-30. [CrossRef]

59. Cordella, T.; Ricci, L.A.; Ruiz-Arranz, M. Debt Overhang or Debt Irrelevance. IMF Staff Pap. 2010, 57, 1-24. [CrossRef]

60. González-Fernández, M.; González-Velasco, C. Shadow economy, corruption and public debt in Spain. J. Policy Model. 2014, 36, 1101-1117. [CrossRef]

61. Cooray, A.; Dzhumashev, R.; Schneider, F. How does corruption affect public debt? An empirical analysis. World Dev. 2017, 90, 115-127. [CrossRef]

62. North, D.C. Institutions, Institutional Change and Economic Performance; Cambridge University: Cambridge, UK, 1990.

63. Égert, B. Regulation, Institutions, and Productivity: New Macroeconomic Evidence from OECD Countries. Am. Econ. Rev. 2016, 106, 109-113. [CrossRef]

64. Dort, T.; Méon, P.-G.; Sekkat, K. Does investment spur growth everywhere? Not where institutions are weak. Kyklos 2014, 67, 482-505. [CrossRef]

65. Berggren, N.; Bergh, A.; Bjornskov, C. What Matters for Growth in Europe? Institutions versus Policies, Quality versus Instability. J. Econ. Policy Reform 2015, 18, 69-88. [CrossRef]

66. Yun, J.J. How do we conquer the growth limits of capitalism? Schumpeterian Dynamics of Open Innovation. J. Open Innov. Technol. Market Complex. 2015, 1, 1-20. [CrossRef]

67. Yun, J.J.; Cooke, P.; Kodama, F.; Phillips, F.; Gupta, A.K.; Gamboa, F.J.C.; Krishna, V.; Lee, K.; Lee, K.; Witt, U.; et al. An open letter to Mr. Secretary General of the United Nations to propose setting up global standards for conquering growth limits of capitalism. J. Open Innov. Technol. Market Complex. 2016, 2, 1-4. [CrossRef]

68. Mauro, P. Corruption and Growth. Q. J. Econ. 1995, 110, 681-712. [CrossRef]

69. Mo, P.H. Corruption and Economic Growth. J. Comp. Econ. 2001, 29, 66-79. [CrossRef]

70. Tanzi, V.; Davoodi, H.R. Corruption, Growth and Public Finances; IMF Working Paper; International Monetary Fund: Washington, DC, USA, 2000.

71. Brunetti, A.; Kisunko, G.; Weder, B. Credibility of Rules and Economic Growth-Evidence from a Worldwide Private Sector Survey; Background Paper for the World Development Report; The World Bank: Washington, DC, USA, 1997.

72. Campos, E.; Lien, D.; Pradhan, S. The impact of corruption on investment: Predictability matters. World Dev. 1999, 27, 1059-1067. [CrossRef]

73. Abed, G.; Davoodi, H. Corruption, structural reforms, and economic performance in the transition economies. In Governance, Corruption, E Economic Performance; Abed, G.T., Gupta, S., Eds.; International Monetary Fund, Publication Services: Washington, DC, USA, 2002.

74. Wei, S.J. How taxing is corruption on international investors? Rev. Econ. Stat. 2000, 82, 1-11. [CrossRef]

75. Lambsdorff, J.G. How corruption affects productivity? Kyklos 2003, 56, 457-474. [CrossRef]

76. Al-Marhubi, F. Corruption and Inflation. Econ. Lett. 2000, 66, 199-202. [CrossRef]

77. Blackburn, K.; Haque, M.E.; Neanidis, K.C. Corruption, Seigniorage and Growth: Theory and Evidence; CESifo Working Paper Series No. 2354, SSRN 1173622; SSRN eLibrary: Munchen, Germany, 2008.

78. Friedman, E.; Johnson, S.; Kaufmann, D.; Zoido-Lobaton, P. Dodging the grabbing hand: the determinants of unofficial activity in 69 countries. J. Publ. Econ. 2000, 76, 459-493. [CrossRef]

79. Johnson, S.; Kaufmann, D.; Shleifer, A. The unofficial economy in transition. Brook. Pap. Econ. Act. 1997, 27, 159-239. [CrossRef]

80. Schneider, F.; Buehn, A.; Montenegro, C. Shadow Economies All over the World: New Estimates for 162 Countries from 1999-2007; World Bank Policy Research Working Paper No. 5356; World Bank: Washington, DC, USA, 2010.

81. Mauro, P. Corruption and the composition of government expenditure. J. Publ. Econ. 1998, 69, $263-279$. [CrossRef]

82. Justesen, M.; Bjornskov, C. Exploiting the poor: Bureaucratic corruption and poverty in Africa. World Dev. 2014, 58, 106-115. [CrossRef] 
83. Dzhumashev, R. Corruption and growth: The role of governance, public spending, and economic development. Econ. Model. 2014, 37, 202-215. [CrossRef]

84. D'Agostino, G.; Dunne, J.P.; Pieroni, L. Corruption and growth in Africa. Eur. J. Political Econ. 2016, 43, 71-88. [CrossRef]

85. D'Agostino, G.; Dunne, J.P.; Pieroni, L. Government spending, corruption and economic growth. World Dev. 2016, 84, 190-205. [CrossRef]

86. Leff, N. Economic development through bureaucratic corruption. Am. Behav. Sci. 1964, 8, 8-14. [CrossRef]

87. Huntington, S.P. Political Order in Changing Societies; Yale University Press: New Haven, CT, USA, 1968.

88. Johnson, E. An economic analysis of corrupt government, with special application for less developed countries. Kylos 1975, 28, 47-61. [CrossRef]

89. Nye, J. Corruption and political development: A cost-benefit analysis. Am. Political Sci. Rev. 1967, 61, 417-427. [CrossRef]

90. Wedeman, A. Looters, rent-scrapers, and dividend-collectors: Corruption and growth in Zaire, South Korea, and the Philippines. J. Dev. Areas 1997, 31, 457-478.

91. Wei, S. Corruption in economic transition and development. In Proceedings of the UNECE Spring Seminar, Geneva, Switzerland, 7-8 May 2001.

92. Lau, C.K.M.; Demir, E.; Bilgin, M.H. Experience-based corporate corruption and stock market volatility: Evidence from emerging markets. Emerg. Mark. Rev. 2013, 17, 1-13. [CrossRef]

93. Acemoglu, D.; Johnson, S.; Querubin, P.; Robinson, J.A. When does policy reform work? The case of central bank independence. Brook. Pap. Econ. Act. 2008, 39, 351429.

94. Aidt, T.S. Corruption, institutions, and economic development. Oxf. Rev. Econ. Policy 2009, 25, $271-291$. [CrossRef]

95. De Rosa, D.; Gooroochurn, N.; Gorg, H. Corruption and Productivity: Firm-Level Evidence from the BEEPS Survey; World Bank Policy Research Working Paper Series 5348; World Bank: Washington, DC, USA, 2010.

96. Meon, P.; Sekkat, K. Does corruption grease or sand the wheels of growth? Publ. Choice 2005, 122, 69-97. [CrossRef]

97. Meon, P.; Weill, L. Is corruption an efficient grease? World Dev. 2010, 38, 244-259. [CrossRef]

98. La Porta, R.; Lopez-de-Silanes, F.; Shleifer, A.; Vishny, R. The quality of government. J. Law Econ. Organ. 1999, 15, 222-279. [CrossRef]

99. Shleifer, A.; Vishny, R. Corruption. Q. J. Econ. 1993, 108, 599-618. [CrossRef]

100. Mendez, F.; Sepulveda, F. Corruption, growth and political regimes: Cross country evidence. Eur. J. Political Econ. 2006, 22, 82-98. [CrossRef]

101. Pattillo, C.; Poirson, H.; Ricci, L.A. Through What Channels Does External Debt Affects Growth? In Brookings Trade Forum; World Bank: Washington, DC, USA, 2003.

102. Park, J. Corruption, soundness of the banking sector, and economic growth: A cross-study. J. Int. Money Financ. 2012, 31, 907-929. [CrossRef]

103. Ciocchini, F.; Durbin, E.; Ng, D. Does Corruption Increase Emerging Market Bond Spreads? J. Econ. Bus. 2003, 55, 503-528. [CrossRef]

104. Myrdal, G. Corruption: Its causes and effects. In Asian Drama: An Inquiry into the Poverty of Nations; Twentieth Century Fund: New York, NY, USA, 1968; Volume II.

105. Krueger, A.O. The Political Economy of the Rent-Seeking Society. Am. Econ. Rev. 1974, 64, 291-303.

106. Shleifer, A.; Vishny, R.W. A survey of corporate governance. J. Financ. 1997, 52, 737-783. [CrossRef]

107. Lui, F.T. An equilibrium queuing model of bribery. J. Political Econ. 1985, 93, 760-781. [CrossRef]

108. Klitgaard, R. Controlling Corruption; University of California Press: Berkeley, CA, USA, 1988.

109. Colombatto, E. Why is corruption tolerated? Rev. Aust. Econ. 2003, 16, 363-379. [CrossRef]

110. Knack, S.; Keefer, P. Institutions and Economic Performance: Cross-Country Tests Using Alternative Institutional Measures. Econ. Politics 1995, 7, 207-227. [CrossRef]

111. Poirson, H. Economic Security, Private Investment, and Growth in Developing Countries; IMF Working Paper; International Monetary Fund: Washington, DC, USA, 1998.

112. Weidmann, J.; Leite, C. Does Mother Nature Corrupt? Natural Resources, Corruption, and Economic Growth; IMF Working Paper; IMF: Washington, DC, USA, 1999.

113. Gyimah-Brempong, K. Corruption, economic growth, and income inequality in Africa. Econ. Gov. 2002, 3, 183-209. [CrossRef] 
114. Wedeman, A. Looters, Rent-Scrapers, and Dividend-Collectors: Corruption and Growth in Zaire, South Korea, and the Philippines. J. Dev. Areas 2005, 31, 457-478.

115. Svensson, J. Eight Questions about Corruption. J. Econ. Perspect. 2005, 19, 19-42. [CrossRef]

116. Assiotis, A.; Sylwester, K. Do the effects of corruption upon growth differ between democracies and autocracies? Rev. Dev. Econ. 2014, 18, 581-594. [CrossRef]

117. Ugur, M. Corruption's Direct Effects on per-capita Income Growth: A meta-analysis. J. Econ. Surv. 2014, 28, 472-490. [CrossRef]

118. Grossman, G.M.; Helpman, E. Innovation and Growth in the Global Economy; MIT Press: Cambridge, MA, USA, 1991.

119. Sala-i-Martin, X.; Doppelhofer, G.; Miller, R.I. Determinants of Long-Term Growth: A Bayesian Averaging of Classical Estimates (BACE) Approach. J. Monet. Econ. 2004, 32, 485-512. [CrossRef]

120. Fischer, S. The role of macroeconomic factors in growth. J. Monet. Econ. 1993, 32, 485-512. [CrossRef]

121. Baldacci, E.; Clements, B.; Gupta, S.; Cui, Q. Social Spending, Human Capital, and Growth in Developing Countries: Implications for Achieving the MDGs; IMF Working Paper, No. wp/04/217; IMF: Washington, DC, USA, 2004.

(c) 2017 by the authors. Licensee MDPI, Basel, Switzerland. This article is an open access article distributed under the terms and conditions of the Creative Commons Attribution (CC BY) license (http:/ / creativecommons.org/licenses/by/4.0/). 